\title{
Palaeogene komatiites from Gorgona Island, East Pacific-A primary magma for ocean floor basalts?
}

\author{
V. J. Dietrich ${ }^{1}$, A. Gansser ${ }^{2}$, J. Sommerauer ${ }^{1}$ and W. E. Cameron ${ }^{3}$ \\ Institut für Kristallographie und Petrographie ${ }^{1}$, ETH-Zürich, and Geologisches Institut ${ }^{2}$, \\ ETH-Zürich, CH-8092 Zürich, Switzerland, Department of Geology ${ }^{3}$, \\ Australian National University, Canberra, Australia 2600
}

(Received March 30, 1981: Accepted May 13, 1981)

\begin{abstract}
Gorgona island is the only place in the world where young ultramafic (pyroxenitic) komatiitic lava flows are known to occur. The island, which appears to be a small southern remnant of the Colombian Coastal Cordillera, is built up of serpentinised peridotites, gabbros, basalts and associated Palaeogene oceanic sediments.

Spinifex texured rocks occur within the basaltic and doleritic complex, closely associated with pillow basalts of tholeiitic composition. During rapid cooling the order of crystallisation was: olivine $\left(\mathrm{Fo}_{90-91}\right)$, high $\mathrm{Al}$-calcic pyroxene and $\mathrm{Cr}$-spinel as the major quenched phases; then olivine $\left(\mathrm{Fo}_{86-82}\right)$. low $\mathrm{Al}$-calcic pyroxene, plagioclase $\left(\mathrm{An}_{75-81}\right)$ and Ti-magnetite as quenched products in the interstitial groundmass. Bulk chemistry: $\mathrm{MgO} \sim 16 \mathrm{wt} . \%\left(\mathrm{Mg} / \mathrm{Mg}+\mathrm{Fe}^{2+}=.74\right), \mathrm{Cr} \sim 1250 \mathrm{ppm}, \mathrm{Ni} \sim 700 \mathrm{ppm}, \mathrm{Sc} \sim 33 \mathrm{ppm}$, $\mathrm{Ba} \sim 5 \mathrm{ppm}, \mathrm{Zr} \sim 30 \mathrm{ppm}, \mathrm{Y} \sim 15 \mathrm{ppm}$; flat REE pattern (5 to $8 \mathrm{x}$ chondrites) with slight depletion of LREE. The associated basalts and dolerites yield similar pattern, although slightly enriched in LREE.

Model calculations incorporating major and trace elements show that fractionation of $20-25 \%$ olivine $+0.5 \% \mathrm{Cr}$-spinel from the komatiitic liquid could produce olivine tholeiites similar to those of Palaeogene Nazca plate. The unique structural setting of the Gorgona rocks probably results from a rapid uplift of a central part of the Nazca ridge including immature magma chambers.
\end{abstract}

\section{INTRODUCTION}

One of us (A.G.) visited the Pacific west coast of Colombia and mapped the Gorgona island during the years 1944 and 1945 while on an exploration assignment with the Shell Oil Co.

The Mesozoic to Palaeogene unmetamorphosed ophiolite complex and the occurrence of the olivine spinifex rocks have already been described by GANSSER (1950). The discovery of their komatiitic nature in 1976 was due to the comparison with the high magnesia boninites dredged from the Mariana trench during the 1976 ophiolite cruise of Dmitri Mendeleev (OBERHAENSLi et al., 1977; Dietrich et al., 1978; PeIVe, 1980). Both quenched rock types have similar olivine $\left(\mathrm{Fo}_{\sim 90}\right)$ and $\mathrm{Cr}$-spinel compositions and thus are good candidates for a discussion on primary basaltic magmas (GANSSER et al, 1979; CAMERON et al., 1979, 1980). This applies particularly for the Gorgona komatiites in respect to their occurrence in a Phanerozoic, non-island arc ophiolite complex and to their chemical affinities to ocean floor tholeiites.

One of the major goals of the present study is the identification of the Gorgona komatiite as a parental liquid composition that may yield fractionated ocean floor tholeiites. This is based on the assumption that these liquids are derived by partial melting from a lherzolitic mantle source, leaving residual harzburgite behind, as has been suggested by BOETTCHER et al. (1975), MYSEN and KUSHIRO (1977), BENDER et al. (1978), Green et al. (1978) and Presnall èt al. (1979).

Only a few occurrences of primitive basalts have been considered to be parental to midocean tholeiites (e.g. FREY et al., 1974; O'NiONS and Clarke, 1972; Elthon, 1979). IRVIN's (1977) calculated primitive liquid composition of abyssal tholeiites requires olivine 
$(\mathrm{Fo} \sim 90.5)$ as the first fractionated mineral. This hypothetical liquid composition is similar to primitive compositions of glass inclusions in olivine and spinel from Mid-Atlantic ridge basalts (Donaldson and Brown, 1977; Dungan and RHODES, 1978).

A major tool in the determination of the nature of primary magmas besides phase equilibria and experimental studies in the system $\mathrm{CaO}-\mathrm{MgO}-\mathrm{Al}_{2} \mathrm{O}_{3}-\mathrm{SiO}_{2}$ is a study of the chemical coherence (using mineral chemistry as well as major, trace and rare earth elements) between natural primitive basaltic volcanics and the vast amount of fractionated tholeiites erupted at

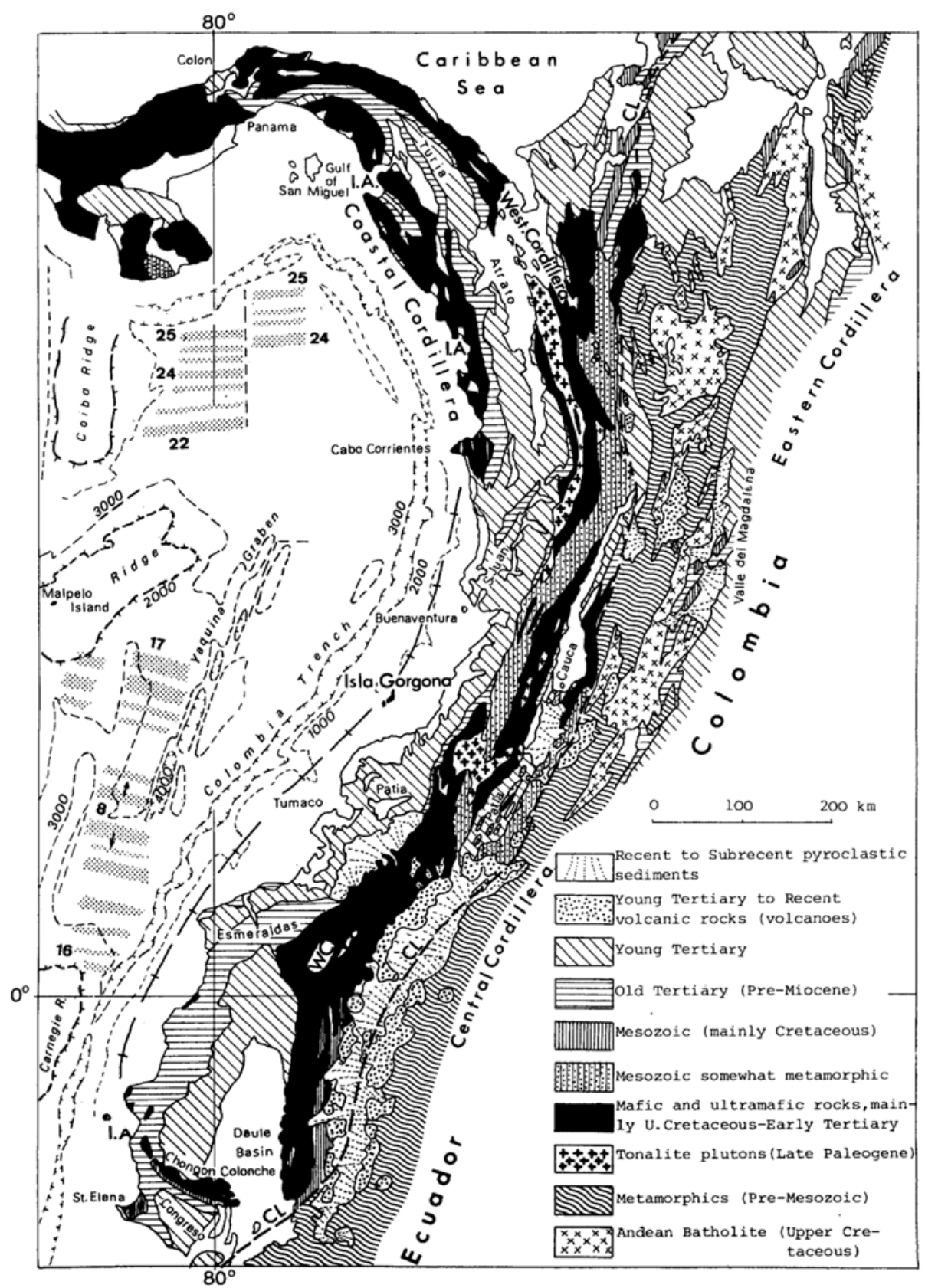

Fig. 1. Tectonic map of NW South-America, modified after GANSSER (1950). Bathymetric contours and magnetic anomalies (numbers in m.y.B.P.) after LONSDALE and KLITGARD (1978). 
mid-ocean ridges. In this perspective the occurrence of pyroxenitic komatiites interlayered with basalts and dolerites on Gorgona island yields a unique situation. In order to clarify the petrogenetic relationship between komatiites and basalts, the full scale of mafic and ultramafic rocks, such as gabbros, cumulates and picrites will be discussed.

\section{Tectonic Setting and Geology of GORGONA ISLAND}

Gorgona island is located on the continental slope (Fig. 1) approximately $80 \mathrm{~km}$ off the Colombian coast at $3^{\circ} \mathrm{N}$ Lat. and $78.2^{\circ} \mathrm{W}$ Long. Tectonically the island appears to be a small southern remnant of the Coastal Cordillera (a northern segment of the Andes: Auboin, 1973; BUtTERLIN , 1973; GANSSER, 1950, 1973), which disappears into the Pacific Ocean at Cabo Corrientes. Gorgona measures $\sim 14 \mathrm{~km}^{2}$ and is accampanied by the much smaller Gorgonilla island (about 1/12 of Gorgona), $1 \mathrm{~km}$ to the south-west.

The Coastal Cordillera between the Gulf of San Miguel (eastern Panamà) and the Chongon Colonche Cordillera (western Ecuador) consists mainly of serpentinised peridotites, gabbros, tholeiitic pillow basalts and flows interbedded with deep water sediments such as Upper Cretaceous radiolarian cherts and limestones. Locally middle Eocene reef limestones and Palaeocene to Eocene siliceous shales form inclusions in the volcanic sequences. These ophiolitetype rocks are overlain by a volcano-sedimentary formation up to $1,000 \mathrm{~m}$ thick (Maestrichtian to Lower Middle Eocene in age) which contains basaltic to andesitic flows. In addition minor dioritic intrusions crosscut the ophiolitic rocks as well as the volcano-sedimentary sequences (BANDY, 1970; DuQUe, 1972; FAUCHER and SAVOYAT, 1973; GANSSER, 1950, 1973; GoOSENS et al., 1977). We consider there to have been at least three Upper Cretaceous to Lower Eocene island arc sequences within the Coastal Cordillera: Chongon Colonche Cordillera, Cabo Marco area (Serrania de Baudo) and in the Gulf of San Miguel area. These sequences are marked with I.A. (island arc) in Fig. 1.

The Gorgona islands are built of approximately ninety percent of mafic and ultramafic rock sequences (Table 1), arranged in several tilted and faulted blocks. Tertiary and Quaternary sediments cover the rest of the islands (for comparison see maps in GANSSER, 1950 and ECHEVERRIA, 1980).

The oldest sediments are Upper Eocene foraminiferal, arenaceous limestones and pyroclastic, siliceous shales rich in radiolaria. They are known only from the southern tip of Gorgonilla island where they dip to the south and continue southwestwards into the single cliff of El Viudo. The contact with the Gorgonilla gabbros may have been originally intrusive, but has subsequently been tectonized. On the west coast of Gorgona faulted siliceous and silty shales occur, containing radiolaria and poorly preserved foraminifera. They are comparable with shales in the Coastal Cordillera and Atrato-San Juan belt of Lower Oligocene age (Fig. 1). On Gorgona the tuffaceous intercalations are missing. Lower Miocene rocks are exposed along the dividing channel, La Tasca, between Gorgona and Gorgonilla islands. The section begins with a coarse conglomerate containing basic igneous and chalcedony pebbles and grades into a thick sandstone and shale sequence. The Lower Miocene is transgressive in the Coastal Cordillera, but here the contacts are faulted. Marine relicts of Middle to Upper Miocene, consisting of foraminiferal arenaceous limestones with some gabbro and diabase pebbles outcrop on the Gorgona east coast, covered by some raised beach terraces. This Miocene section represents the transgressive tail end of the thick Atrato-San Juan basin sediments.

Unmetamorphosed ultramafic rocks (mainly weakly layered dunites and wehrlites) occur within the gabbros: in the middle part of Gorgonilla island and in the middle part of the west coast of Gorgona island (GANSSER, 1950). Further investigations of ECHEVERRIA and PARIS in 1978 have proved the existence of other occurrences, particularly in the 
interior of the island along a major axial fault (ECHEVERRIA, 1980), where mapping is greatly handicapped by most luxurious tropical rain forests.

The gabbros, including some olivine gabbro and troctolite with pronounced cumulate textures, constitute the central part of Gorgona island and the southern part of Gorgonilla island. The contacts to the underlying ultramafics are clearly transitional except in places where faulting has occurred. Olivine and spinel are poikilitically enclosed by clinopyroxene. Plagioclase fills the interstices. Ophitic textures dominate in the upper levels of the gabbroic units, which gradually pass into dolerites.

Alteration and secondary rodingitisation are present in many outcrops of the ultramafic and gabbroic rocks. Olivine is often serpentinised, the rocks are typically mesh-texured consisting of chrysotile, lizardite, magnetite, chlorite assemblages. Plagioclase-rich parts in the cumulates have been transformed to a prehnitehydrogrossular assemblage; clinopyroxene shows actinolitic fringes. In most cases the dark green clinopyroxene-gabbros display a coarse grained ophitic texture, with minor occurrences of pegmatitic patches.

Of special interest is the Eocene limestone-

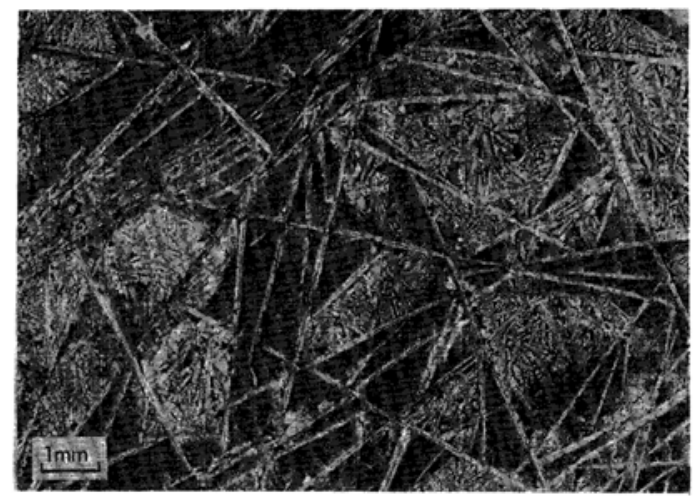

Fig. 2. Spinifex-textured komatiite from Gorgona island. Sample (49) from the upper surface of the ultramafic lava flow at Punta Trinidad. Weakly serpentinised skeletal olivine plates $\left(\mathrm{Fo}_{86-85}\right)$ causing a pronounced octahedral cleavage at the rock surface. The quenched groundmass consists of clinopyroxene aggregates, glass with plumose extinction and partly quenched magnesiochromite. gabbro contact on Gorgonilla island. The nodular, honeycoloured chalcedony lenses and bands, usually $5-20 \mathrm{~cm}$ thick, are aligned along the contact. These rocks are known from several ophiolite occurrences in the Coastal Cordillera.

Diabases and basalts are concentrated along both sides of Gorgona island, and in the northern part of Gorgonilla island. On map scale the diabases are rather uniform, in detail, however, many minor differences can be recognized. The subdivision from the gabbros is in many places arbitrary. Often it is difficult to decide whether a rock should be called a coarse fresh diabase, a partly altered dolerite with subophitic textures or a fine-grained gabbro. To date sheeted dikes have not been recognized within the gabbroic complex. Sills and flows seem to be the predominant structural features. Pillow lavas are well exposed in the northern part at Boca el Horno.

Hyaloclastites form the southern part of the Gorgona island where they are in faulted contact with diabases to the north and Lower Miocene sediments to the west. They dip gently southwards, similar to the Eocene sediments of Gorgonilla. This $500 \mathrm{~m}$ thick section is most varied, and consists of well bedded hyaloclastites, pillow lavas and diabase-breccias. Under the microscope, the finer tuffs exhibit a very irregular

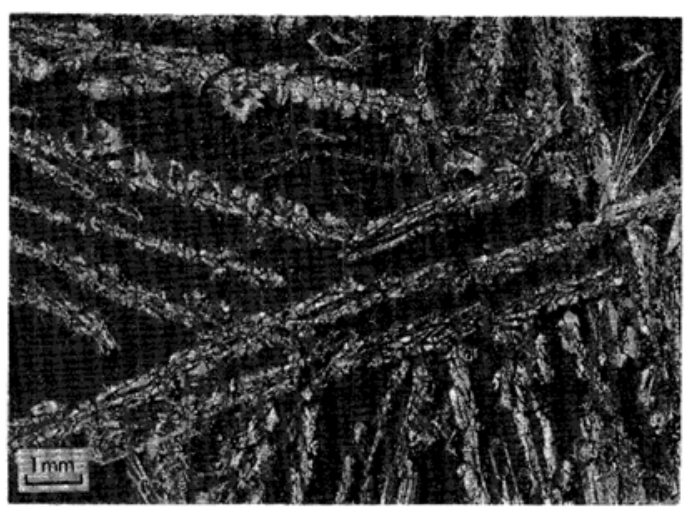

Fig. 3. Coarse spinifex-textured inner part of the same komatiitic flow (sample 48). Large, zoned skeletal olivine plates (Fo $\left.{ }_{91-83}\right)$ and smaller skeletal high-Al clinopyroxenes in fine grained arborescent groundmass of plagioclase, clinopyroxene and titanomagnetite. 
and patchy network of fine augite needles in a palagonite and chlorite groundmass. The age of the hyaloclastites is not clear. It may be related to the northern basaltic complex capping the pillow basalts and most likely forming the base of the Gorgonilla Eocene sediments.

Komatiitic flows, exhibiting typical spinifex textures, have been found by GANSSER (1950) in two localities of Gorgona Island: on the east coast at Punta Trinidad and on the west coast at La Mancura. In addition EcHEVERriA (1980) reported five other occurrences from both sides of the island within the basalt and diabase complex.

Of exceptional interest are the fresh komatiitic flows at Punta Trinidad. There, the flows seem to be interlayered between gabbros and basalts.

The distinctive textural habits of these ultramafic rocks are readily apparent upon inspection. The dark green, massive flows of up to one meter thickness are characterised by two principal textures: A "coarse arborescent spinifex" texture (Fig. 3), caused by shiny 5 to $8 \mathrm{~cm}$ long skeletal olivine blades; and an "octahedral" texture (Fig. 2), where the rock surface exhibits a pronounced octahedral cleavage. The latter, actual surface on the outcrops, is also caused by the spinifex arrangement of fine, randomly oriented (up to $2 \mathrm{~cm}$ long) olivine blades in an aphanitic matrix of partly altered glass, while coarse spinifex textures dominate the interior parts of these outcrops. The bottom part of the flows are made up by olivine and pyroxene with cumulate textures. In this respect the Gorgona spinifex flows closely resemble the pyroxenitic and peridotitic komatiite flows at Munro Township (Ontario) described in detail by PYKE et al. (1973) and ARNDT et al. (1977).

\section{Analytical Techniques}

Mineral compositions were analyzed using an ARL electron microprobe type SEMQ equipped

Table 1. Mineralogy of the selected mafic and ultramafic rocks from the Gorgona islands

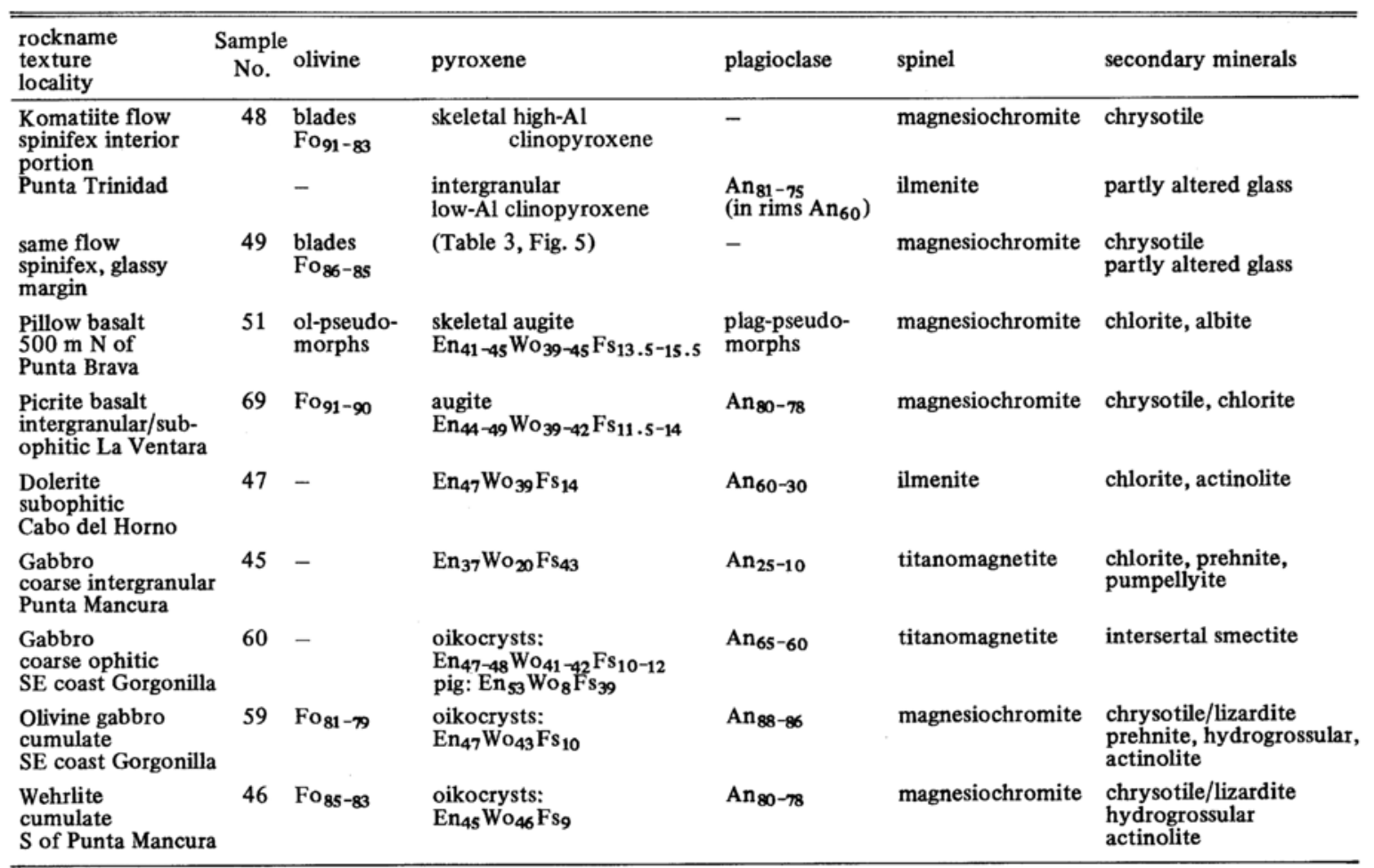


Table 2. Representative olivine analyses

\begin{tabular}{|c|c|c|c|c|c|c|}
\hline & Komatiites & & & & Picrite basalt & Wehrlite \\
\hline $\begin{array}{l}\text { Sample } \\
\text { No. }\end{array}$ & $\begin{array}{c}48 \\
\begin{array}{c}\text { Centre of } \\
\text { blade }\end{array} \\
\end{array}$ & $\begin{array}{c}48 \\
\text { "lantern" } \\
\text { olivine }\end{array}$ & $\begin{array}{c}48 \\
\text { margin of } \\
\text { blade }\end{array}$ & $\begin{array}{c}49 \\
\text { blade }\end{array}$ & $\begin{array}{c}69 \\
\text { phenocrysts }\end{array}$ & $\begin{array}{c}46 \\
\text { cumulate }\end{array}$ \\
\hline $\mathrm{SiO}_{2}$ & 40.6 & 40.2 & 39.5 & 40.3 & 41.2 & 40.3 \\
\hline $\mathrm{FeO}^{*}$ & 10.0 & 13.1 & 14.6 & 13.7 & 8.7 & 15.5 \\
\hline $\mathrm{MgO}$ & 48.6 & 45.9 & 44.4 & 45.1 & 49.6 & 44.3 \\
\hline $\mathrm{MnO}$ & 0.16 & 0.20 & 0.18 & 0.20 & 0.13 & 0.24 \\
\hline $\mathrm{CaO}$ & 0.33 & 0.34 & 0.40 & 0.42 & 0.32 & 0.30 \\
\hline $\mathrm{NiO}$ & 0.44 & 0.33 & 0.22 & 0.30 & 0.41 & 0.19 \\
\hline $\mathrm{Cr}_{2} \mathrm{O}_{3}$ & 0.12 & 0.10 & 0.15 & 0.13 & 0.12 & 0.02 \\
\hline \multirow[t]{2}{*}{ Total } & 100.2 & 100.2 & 99.5 & 100.1 & 100.5 & 100.8 \\
\hline & \multicolumn{4}{|c|}{ Cations to 4 oxygens } & & \\
\hline $\mathrm{Si}$ & 0.996 & 1.001 & 0.997 & 1.007 & 1.003 & 1.007 \\
\hline $\mathrm{Fe}$ & 0.205 & 0.272 & 0.308 & 0.287 & 0.178 & 0.323 \\
\hline $\mathrm{Mg}$ & 1.776 & 1.704 & 1.671 & 1.682 & 1.798 & 1.650 \\
\hline Mn & 0.004 & 0.004 & 0.004 & 0.004 & 0.003 & 0.005 \\
\hline $\mathrm{Ca}$ & 0.009 & 0.009 & 0.012 & 0.011 & 0.008 & 0.008 \\
\hline $\mathrm{Ni}$ & 0.009 & 0.007 & 0.004 & 0.007 & 0.009 & 0.003 \\
\hline \multirow{3}{*}{$\begin{array}{l}\mathrm{Cr} \\
{[\mathrm{Y}]}\end{array}$} & 0.003 & 0.002 & 0.003 & 0.003 & 0.002 & 0.000 \\
\hline & 2.006 & 1.998 & 2.002 & 1.994 & 1.998 & 1.989 \\
\hline & $\mathrm{Fo}_{99.7}$ & $\mathrm{Fo}_{86.2}$ & $\mathrm{Fo}_{84.4}$ & $\mathrm{Fo}_{85.4}$ & $\mathrm{Fo}_{91.0}$ & $\mathrm{Fo}_{83.6}$ \\
\hline
\end{tabular}

*Total iron expressed as $\mathrm{FeO}$.

Blades $\mathrm{Fo}_{91}-\mathrm{Fo}_{88}$ in centres

$\mathrm{Fo}_{87-83}$ in margins

Table 3. Representative pyroxene analyses

\begin{tabular}{|c|c|c|c|c|c|c|c|c|c|c|c|}
\hline $\begin{array}{l}\text { Sample } \\
\text { No. }\end{array}$ & $\begin{array}{l}48 \\
\text { skeletal p } \\
\text { xene }\end{array}$ & $\begin{array}{r}48 \\
\text { yro- }\end{array}$ & $\begin{array}{l}48 \\
\text { intergrar } \\
\text { (with pl } \\
\text { and Ti-m }\end{array}$ & $\begin{array}{l}\quad 48 \\
\text { ar } \\
\text { oclase } \\
\text { netite) }\end{array}$ & $\begin{array}{c}49 \\
\text { skeletal }\end{array}$ & $\begin{array}{c}49 \\
\text { pyroxenes }\end{array}$ & 49 & \begin{tabular}{l}
\multicolumn{5}{c}{51} \\
skeletal p \\
senes
\end{tabular} & $\begin{array}{c}51 \\
\text { yro- }\end{array}$ & $\begin{array}{l}69 \\
\text { micro- } \\
\text { pheno- } \\
\text { cryst }\end{array}$ & $\begin{array}{c}69 \\
\text { inter- } \\
\text { granular }\end{array}$ \\
\hline $\mathrm{SiO}_{2}$ & 45.0 & 47.6 & 49.4 & 50.4 & 47.4 & 46.7 & 45.3 & 50.9 & 49.4 & 53.2 & 50.3 \\
\hline $\mathrm{TiO}_{2}$ & 1.1 & 0.73 & 0.98 & 0.79 & 0.88 & 0.85 & 1.0 & 0.86 & 1.02 & 0.26 & 0.63 \\
\hline $\mathrm{Al}_{2} \mathrm{O}_{3}$ & 11.5 & 7.7 & 3.8 & 2.1 & 8.9 & 11.3 & 13.1 & 4.5 & 5.3 & 2.6 & 4.8 \\
\hline $\mathrm{FeO}^{*}$ & 6.8 & 12.0 & 14.7 & 18.2 & 9.5 & 9.5 & 7.5 & 9.4 & 8.2 & 7.3 & 8.6 \\
\hline $\mathrm{MnO}$ & 0.10 & 0.29 & 0.31 & 0.41 & 0.19 & 0.26 & 0.14 & 0.25 & 0.19 & 0.23 & 0.19 \\
\hline $\mathrm{MgO}$ & 11.9 & 11.7 & 12.8 & 11.4 & 15.2 & 13.5 & 10.6 & 15.4 & 13.9 & 17.7 & 15.0 \\
\hline $\mathrm{CaO}$ & 22.4 & 18.9 & 18.9 & 18.1 & 17.0 & 18.3 & 23.0 & 18.8 & 21.2 & 19.1 & 19.8 \\
\hline $\mathrm{Na}_{2} \mathrm{O}$ & 0.20 & 0.21 & 0.16 & - & 0.20 & 0.16 & 0.16 & 0.21 & 0.17 & 0.16 & 0.24 \\
\hline $\mathrm{Cr}_{2} \mathrm{O}_{3}$ & 0.18 & 0.08 & - & - & 0.27 & 0.21 & 0.19 & 0.35 & 0.27 & 0.31 & 0.11 \\
\hline Total & 99.2 & 99.2 & 101.0 & 101.4 & 99.5 & 100.8 & 101.0 & 100.7 & 99.7 & 100.9 & 99.6 \\
\hline En & $37.3(47.5)$ & $36.5(41$. & 0) 36.9 & 32.9 & $46.3(54.8)$ & $42.2(50.9)$ & $33.9(42.0)$ & 45.2 & 41.3 & 49.7 & 43.9 \\
\hline Wo & $50.7(43.0)$ & $42.5(36$ & 5) 39.2 & 37.7 & $37.3(29.6)$ & $41.2(31.6)$ & $52.7(44.4)$ & 39.4 & 45.0 & 38.8 & 42.0 \\
\hline Fs & $12.0(9.5)$ & $21.0(22$ & 5) 23.8 & 29.4 & $16.4(15.6)$ & $16.6(17.6)$ & $13.4(13.6)$ & 15.4 & 13.7 & 11.5 & 14.1 \\
\hline
\end{tabular}

* Total iron expressed as $\mathrm{FeO}$.

Values for EnWoFs in brackets : $\mathrm{CaAl}_{2} \mathrm{SiO}_{6}$ (Tschermaks-molecule) subtracted

with four motor driven X-ray spectrometers and For each analysis the 10 elements as listed in two fixed X-ray monochromators (set for $\mathrm{Si}$ Tables 2, 3 and 4 were determined. For reference and $\mathrm{Mg}$, respectively). The following operating conditions were applied: $15 \mathrm{KV}$ acceleration voltage, $20 \mathrm{nA}$ sample current measured on brass intensities, natural silicates and oxides were applied.

Reasonable counting times were used to and a minimum electron beam size of $0.2 \mu \mathrm{m}$. yield a standard deviation of the counting 
Table 4. Representative spinel analyses

\begin{tabular}{|c|c|c|c|c|c|c|}
\hline \multirow[b]{2}{*}{ Sample No. } & \multicolumn{3}{|c|}{ Magnesiochromites } & \multirow[b]{2}{*}{69} & \multicolumn{2}{|c|}{ Titanomagnetite } \\
\hline & 48 & 49 & 51 & & 46 & 48 \\
\hline $\mathrm{SiO}_{2}$ & 0.09 & 0.12 & 0.11 & 0.16 & 0.07 & - \\
\hline $\mathrm{TiO}_{2}$ & 0.41 & 0.45 & 0.56 & 0.17 & 0.80 & 18.49 \\
\hline $\mathrm{Al}_{2} \mathrm{O}_{3}$ & 20.28 & 22.38 & 21.02 & 20.13 & 20.26 & 2.98 \\
\hline $\mathrm{Cr}_{2} \mathrm{O}_{3}$ & 46.41 & 43.31 & 40.83 & 47.03 & 35.32 & - \\
\hline $\mathrm{Fe}_{2} \mathrm{O}_{3}{ }^{+}$ & 6.06 & 6.06 & 7.00 & 3.98 & 13.15 & 27.83 \\
\hline $\mathrm{FeO}$ & 9.62 & 9.99 & 15.34 & 13.57 & 17.99 & 46.38 \\
\hline $\mathrm{MgO}$ & 16.67 & 16.61 & 12.81 & 14.09 & 11.20 & - \\
\hline $\mathrm{MnO}$ & 0.29 & 0.24 & n.d. & n.d. & 0.38 & 1.65 \\
\hline $\mathrm{NiO}$ & 0.30 & 0.25 & 0.15 & 0.17 & 0.15 & - \\
\hline Total & 100.13 & 99.41 & 97.82 & 99.30 & 99.32 & 97.83 \\
\hline $\mathrm{Si}$ & 0.022 & 0.029 & 0.028 & 0.040 & 0.018 & - \\
\hline $\mathrm{Ti}$ & 0.075 & 0.082 & 0.106 & 0.032 & 0.153 & 4.233 \\
\hline $\mathrm{Al}$ & 5.800 & 6.386 & 6.255 & 5.889 & 6.075 & 1.069 \\
\hline $\mathrm{Cr}$ & 8.901 & 8.288 & 8.147 & 9.266 & 7.102 & 6.343 \\
\hline $\mathrm{Fe}^{3+}$ & 1.106 & 1.104 & 1.329 & 0.743 & 2.517 & 0.122 \\
\hline $\mathrm{Fe}^{2+}$ & 1.952 & 2.021 & 3.239 & 2.816 & 3.826 & 11.807 \\
\hline $\mathrm{Mg}$ & 6.027 & 5.992 & 4.819 & 5.211 & 4.245 & - \\
\hline Mn & 0.060 & 0.049 & n.d. & n.d. & 0.082 & 0.425 \\
\hline $\mathrm{Ni}$ & 0.059 & 0.049 & 0.030 & 0.034 & 0.030 & - \\
\hline $\mathrm{Mg} /\left(\mathrm{Mg}+\mathrm{Fe}^{2+}\right)$ & 0.755 & 0.748 & 0.598 & 0.649 & 0.526 & $\mathrm{Ulv}_{56} \mathrm{Mgt}_{44}$ \\
\hline $\mathrm{Cr} /(\mathrm{Cr}+\mathrm{Al})$ & 0.605 & 0.565 & 0.566 & 0.610 & 0.539 & \\
\hline $\mathrm{Fe}^{3+} /\left(\mathrm{Fe}^{3+}+\mathrm{Cr}+\mathrm{Al}\right)$ & 0.070 & 0.070 & 0.084 & 0.047 & 0.160 & \\
\hline
\end{tabular}

$\mathrm{Fe}_{2} \mathrm{O}_{3}^{+}$calculated assuming stoichiometry

n.d. $=$ not determined

statistics better than $1 \%$ for minor elements. Up to 10 analyses were averaged to determine the mineral compositions. The accumulated counts were corrected on-line for background, drift and dead-time with a PDP-11/05 computer. Correction procedures for X-ray absorption, X-ray fluorescence (by characteristic and continuum excitation, respectively), and atomic number effects were based on a ZAF correction program written for the CDC 6500 computer system at the ETH Zürich.

Major element bulk chemical X-ray fluorescence analyses (Table 5) of 9 glass beads fused from ignited powers plus $\mathrm{Li}_{2} \mathrm{~B}_{4} \mathrm{O}_{7}(1 / 5$ ratio in gold-platinum pan at $1150^{\circ} \mathrm{C}$ : DIETRICH et al., 1976) were obtained on an automated Philips sequential spectrometer PW 1450 at the EMPA Dübendorf, Switzerland. Computer programs were applied for correction of drift, background and matrix effects. Twelve US-Geological Survey reference rock samples were used for calibration. $\mathrm{FeO}$ and $\mathrm{H}_{2} \mathrm{O}$ determinations were done by wet chemical methods. $\mathrm{Nb}, \mathrm{Zr}, \mathrm{Y}, \mathrm{Sr}$,
$\mathrm{U}, \mathrm{Rb}, \mathrm{Th}, \mathrm{Pb}, \mathrm{Ga}, \mathrm{Zn}, \mathrm{Cu}, \mathrm{Ni}, \mathrm{Co}, \mathrm{Cr}, \mathrm{V}, \mathrm{Ce}$, $\mathrm{Nd}, \mathrm{Ba}, \mathrm{La}, \mathrm{Sc}$, and $\mathrm{S}$ trace-element abundances were also analysed by X-ray fluorescence on $10 \mathrm{~g}$ power samples using the synthetic background method, if major element contents were known. A computer program was used to calculate background, interference, mass absorption and standard deviations (NiSBET et al., 1979). The same USGS reference samples as above were used for calibration. The accuracy is $\pm 2-3 \%$ at $\sim 1000 \mathrm{ppm}, \pm 5-10 \%$ at $\sim 100 \mathrm{ppm}$ and $\pm 10-20 \%$ at $10 \mathrm{ppm}$. Using a Cr-tube, the detection limits are around $3 \mathrm{ppm}$ for most of the trace elements.

REE abundances (Table 6) of nine selected samples have been analysed by radiochemical neutron activation analysis (RNAA) at the EIR-Würenlingen, Switzerland (BAJO and WYTTENBACH, 1980). BCR-1 prepared in the same manner as the unknowns yielded $\mathrm{La}=26.6$ $\pm 0.2, \mathrm{Ce}=54.0 \pm 0.9, \mathrm{Nd}=29.4 \pm 0.5, \mathrm{Sm} 7.1$ $\pm 0.04, \mathrm{Eu}=1.91 \pm 0.014, \mathrm{Gd}=6.86 \pm 0.17, \mathrm{~Tb}$ $=1.01 \pm 0.018, \mathrm{Tm}=0.621 \pm 0.013, \mathrm{Yb}=$ 
Table 5. Chemical composition of representative rock types from Gorgona Island

\begin{tabular}{|c|c|c|c|c|c|c|c|c|c|}
\hline \multirow{2}{*}{$\begin{array}{l}\text { wt. } \% \\
\text { Sample No. }\end{array}$} & \multicolumn{2}{|c|}{ Komatiites* } & \multicolumn{2}{|c|}{ Basalts } & \multirow{2}{*}{$\begin{array}{c}\text { Dolerite } \\
47\end{array}$} & \multicolumn{3}{|c|}{ Gabbros } & \multirow{2}{*}{$\begin{array}{c}\text { Wehrlite } \\
46\end{array}$} \\
\hline & 48 & 49 & 51 & 69 & & 45 & 60 & 59 & \\
\hline $\mathrm{SiO}_{2}$ & 44.2 & 44.0 & 47.8 & 44.2 & 52.2 & 45.0 & 47.7 & 42.1 & 39.5 \\
\hline $\mathrm{TiO}_{2}$ & 0.66 & 0.72 & 0.89 & 0.35 & 1.3 & 0.91 & 1.1 & 0.33 & 0.28 \\
\hline $\mathrm{Al}_{2} \mathrm{O}_{3}$ & 12.0 & 12.6 & 14.6 & 10.0 & 13.6 & 17.2 & 15.5 & 12.7 & 5.5 \\
\hline $\mathrm{Fe}_{2} \mathrm{O}_{3}$ & 3.2 & 4.0 & 1.8 & 3.0 & 3.5 & 2.1 & 1.9 & 1.8 & 2.5 \\
\hline $\mathrm{FeO}$ & 8.2 & 7.6 & 8.1 & 7.3 & 8.1 & 8.1 & 7.9 & 8.6 & 9.9 \\
\hline $\mathrm{MnO}$ & 0.18 & 0.18 & 0.17 & 0.17 & 0.17 & 0.17 & 0.17 & 0.16 & 0.19 \\
\hline $\mathrm{MgO}$ & 15.9 & 14.2 & 8.9 & 22.7 & 6.6 & 6.1 & 7.4 & 20.6 & 30.2 \\
\hline $\mathrm{CaO}$ & 10.1 & 11.5 & 11.2 & 8.5 & 10.1 & 14.7 & 11.8 & 8.9 & 5.3 \\
\hline $\mathrm{Na}_{2} \mathrm{O}$ & 1.13 & 1.05 & 2.9 & 0.78 & 3.0 & 1.9 & 2.8 & 0.70 & 0.10 \\
\hline $\mathrm{K}_{2} \mathrm{O}$ & 0.02 & 0.07 & 0.08 & 0.01 & 0.24 & 0.17 & 0.08 & 0.02 & 0.00 \\
\hline $\mathrm{P}_{2} \mathrm{O}_{5}$ & 0.06 & 0.06 & 0.08 & 0.04 & 0.12 & 0.09 & 0.09 & 0.04 & 0.04 \\
\hline $\mathrm{H}_{2} \mathrm{O}+$ & 4.0 & 3.7 & 3.3 & 2.8 & 1.2 & 3.6 & 2.3 & 4.0 & 6.0 \\
\hline Total & 99.7 & 99.6 & 99.8 & 99.9 & 100.1 & 100.0 & 98.8 & 99.9 & 99.4 \\
\hline $\mathrm{Mg} /\left(\mathrm{Mg}+\mathrm{Fe}^{2+}\right)$ & 0.74 & 0.72 & 0.65 & 0.82 & 0.54 & 0.55 & 0.60 & 0.80 & 0.83 \\
\hline \multicolumn{10}{|c|}{ Trace elements (ppm) } \\
\hline $\mathrm{Ni}$ & 720 & 560 & 150 & 1040 & 68 & 54 & 100 & 710 & 1180 \\
\hline $\mathrm{Cr}$ & 1250 & 1180 & 390 & 2180 & 85 & 160 & 150 & 840 & 1280 \\
\hline Co & 94 & 72 & 53 & 103 & 56 & 47 & 47 & 109 & 138 \\
\hline V & 260 & 290 & 290 & 180 & 380 & 290 & 330 & 115 & 90 \\
\hline Sc & 31 & 36 & 43 & 29 & 49 & 38 & 42 & 14 & 14 \\
\hline $\mathrm{Ga}$ & 15 & 14 & 14 & 10 & 17 & 16 & 16 & 11 & 8 \\
\hline $\mathrm{Zn}$ & 57 & 63 & 72 & 50 & 92 & 65 & 57 & 53 & 53 \\
\hline $\mathrm{Cu}$ & 150 & 117 & 100 & 70 & 167 & 143 & 198 & 34 & 43 \\
\hline $\mathrm{Y}$ & 14 & 15 & 14 & 8 & 23 & 21 & 12 & 4 & 1 \\
\hline $\mathrm{Zr}_{\mathbf{r}}$ & 30 & 33 & 41 & 8 & 67 & 43 & 41 & 7 & 5 \\
\hline $\mathrm{Nb}$ & 0.5 & 0.5 & 1 & $\langle 1$ & 3 & 2 & 2 & 1 & 1 \\
\hline $\mathbf{R b}$ & 1 & 1 & 1 & $\langle 1$ & 3 & 2 & 1 & $<1$ & $\langle 1$ \\
\hline $\mathrm{Sr}$ & 58 & 50 & 128 & 20 & 104 & 132 & 115 & 71 & 30 \\
\hline $\mathrm{Ba}$ & 3 & 6 & 19 & 4 & 31 & 41 & 51 & 13 & 3 \\
\hline $\mathbf{S}$ & 109 & 95 & 505 & 51 & 640 & 820 & 450 & 308 & 210 \\
\hline
\end{tabular}

* Analyses of No. 48 and 49 are mean of 4 determinations. $Y, Z r, N b, B a, R b$ on these samples also by B.W. CHAPPEL (XRF). Mg-values calculated on the basis of $\mathrm{Fe}^{3+} /\left(\mathrm{Fe}^{2+}+\mathrm{Fe}^{3+}\right)=0.1$.

$3.360 \pm 0.03, \mathrm{Lu}=0.54 \pm 0.005$. In addition REE from two komatiite samples Nos. 48 and 49 were determined by spark source emission spectrography at ANU Canberra using the technique of TAYLOR and GORTON (1977).

\section{Petrography and Phase Chemistry}

Nine characteristic rock types (Tab. 1) exhibiting the least alteration have been chosen from the original collection (GANSSER, 1950) to show the mineralogical and chemical variety of the ultramafic and mafic rocks from Gorgona and Gorgonilla islands.

Olivine Selected olivine analyses for komatiites, a picrite basalt and a wehrlite are listed in Table 2. The large (up to $5 \mathrm{~cm}$ long olivine plates (Fig. 3) in the spinifex part of the komatiitic flows are zoned, with $\mathrm{FO}_{91-88}$ in the centres and $\mathrm{Fo}_{87-83}$ in the margins. Ni decreases towards the rims whereas $\mathrm{Cr}$ and $\mathrm{Ca}$ slightly increase. High magnesian olivine $\left(\mathrm{Fo}_{91-89}\right)$ is frequent in the picrite basalt, low values are abundant in the cumulate rocks $\left(\mathrm{FO}_{84}\right.$ in wehrlite and $\mathrm{Fo}_{81-79}$ in olivine gabbro).

Crystallisation temperatures of $1400-1500$ ${ }^{\circ} \mathrm{C}$ for the komatiitic flows were calculated using olivine-spinel geothermometer (ENGi, 1978 or ROEDER et al., 1979). The lower temperatures of ca. $900^{\circ} \mathrm{C}$ for the picrite and of $850-900^{\circ} \mathrm{C}$ for the cumulates may be interpreted as subsolidus reequilibration temperatures.

Clinopyroxene Clinopyroxene compositions are shown in Table 3, and the crystallisation 


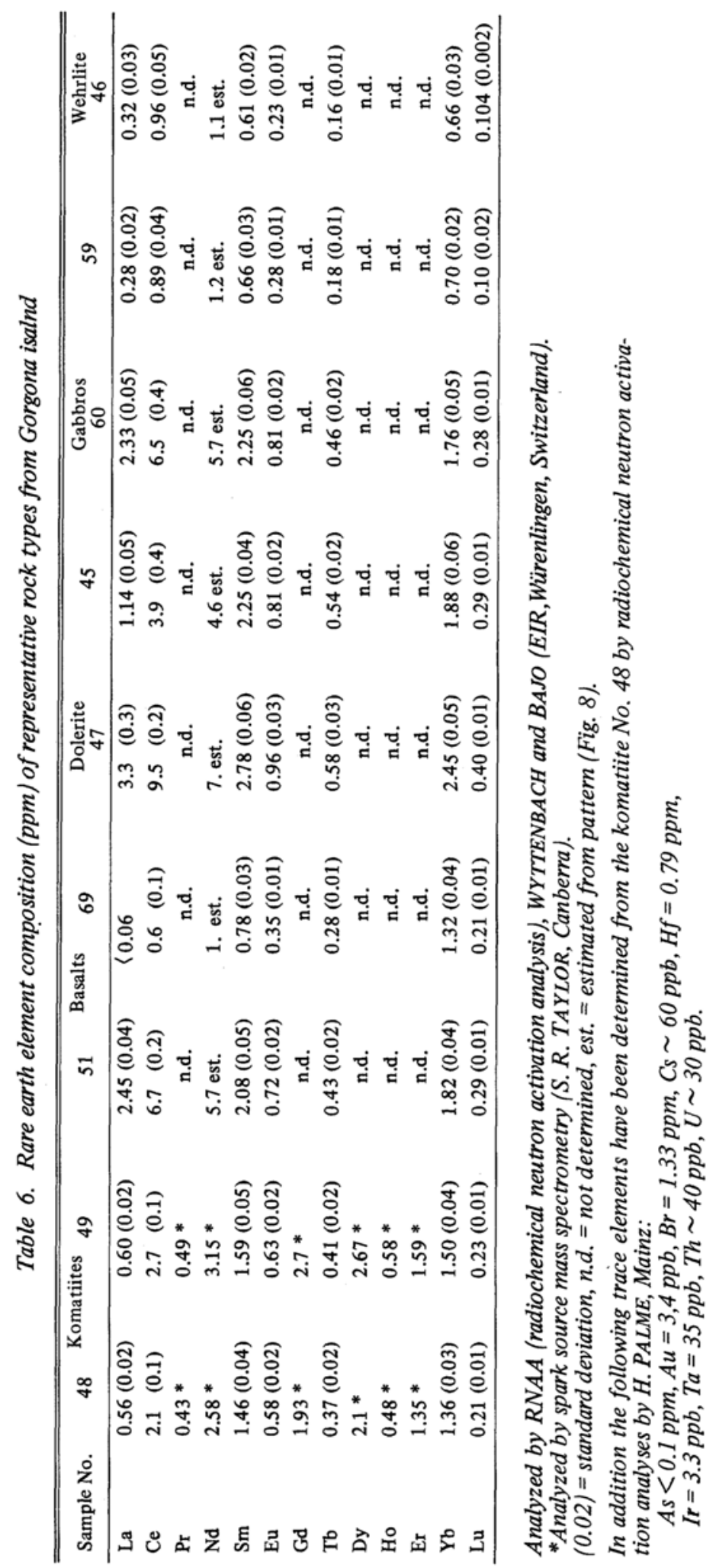


paths in Fig. 6. Rather unusual compositions are present in the large, up to $2 \mathrm{~mm}$ "harpoon"type skeletal augites (Fig. 4), (GANSSER, 1950). These first crystallising pyroxenes yield extremely high $\mathrm{Al}_{2} \mathrm{O}_{3}$ (up to 13 wt.\%), high $\mathrm{CaO}$ (up to 23 wt.\%) and $\mathrm{TiO}_{2}$ (up to 1.1 wt.\%). Ca occupies $\mathrm{M}(2)$ sites, $\mathrm{Al}$ can enter both the tetrahedral coordination (Ca-Tschermaks molecule) and the octahedral $\mathrm{M}(1)$ site and $\mathrm{Ti}$ can be expressed as $\mathrm{CaTiAl}_{2} \mathrm{O}_{6}$. Recent experimental investigations indicate minimum temperatures on the liquidus of about $1230^{\circ} \mathrm{C}$ for high $\mathrm{Al}$

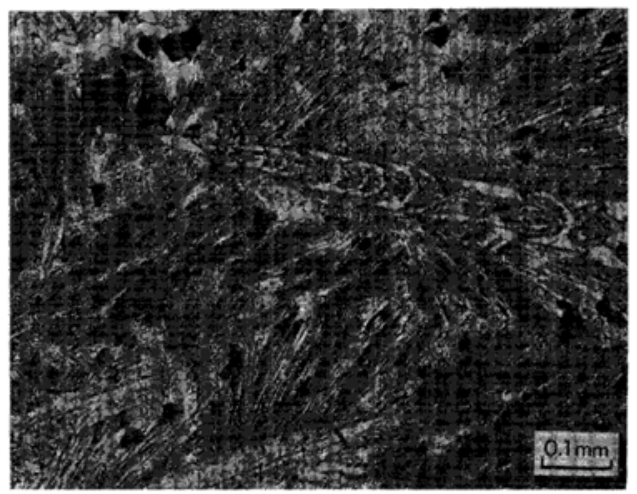

Fig. 4. Close up of the arborescent, intergranular material of sample 48. Skeletal high-Al clinopyroxene and partly euhedral magnesiochromite in aggregates of plagioclase $\left(A n_{75-81}\right), F e-$ rich clinopyroxene and irregularly distributed titanomagnetite.

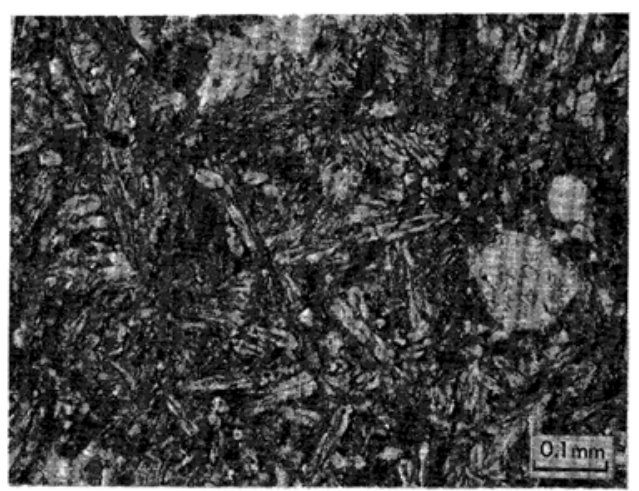

Fig. 5. Photomicrograph of pillow basalt (sample 51 from Punta Brava) partly feathery and skeletal clinopyroxene microlites with few magnesiochromites (black). Fine grained plagioclase laths transformed to albite, minor olivine microphenocrysts replaced by chlorite. In addition chlorite filled vescicles. and Ti-bearing clinopyroxenes (AKASAKA and ONuma, 1980; HuebNER, 1980). In contrast the fine-grained, arborescent, intergranular clinopyroxenes (Fig. 4) tend to be enriched in silica, iron and manganese, whereas $\mathrm{Ca}, \mathrm{Al}$, and $\mathrm{Cr}$ values are lower. Thus these phases (transition to ferroaugites) indicate a more evolved stage during the process of rapid cooling. Clinopyroxene from the nodular bottom parts of the komatiitic flows are lower in $\mathrm{Al}_{2} \mathrm{O}_{3}$ (0.3 to 2.6 wt.\%; ECHEVERRIA, 1980) indicating slow crystallisation. Pigeonite or orthopyroxene have not been found in the komatiites. Subophitic and intergranular clinopyroxenes from the cumulate rocks, gabbros, dolerites and basalts depict the normal trend of differentiation (stippled field in Fig. 6). Their $\mathrm{Al}_{2} \mathrm{O}_{3}$-variation lies between 2 and 4wt.\%. The cpx compositions reach $\mathrm{En}_{38} \mathrm{Wo}_{42} \mathrm{Fs}_{20}$, with respect to the iron enrichment in olivine. The internal part of a pillowlava consists of small groundmass skeletal clinopyroxene (Fig. 6) revealing $\mathrm{Al}_{2} \mathrm{O}_{3}$ values up to $5.3 \mathrm{wt} . \%$ and $\mathrm{CaO}$ values of $21.2 \mathrm{wt} . \%$. These compositions overlap with those of the first

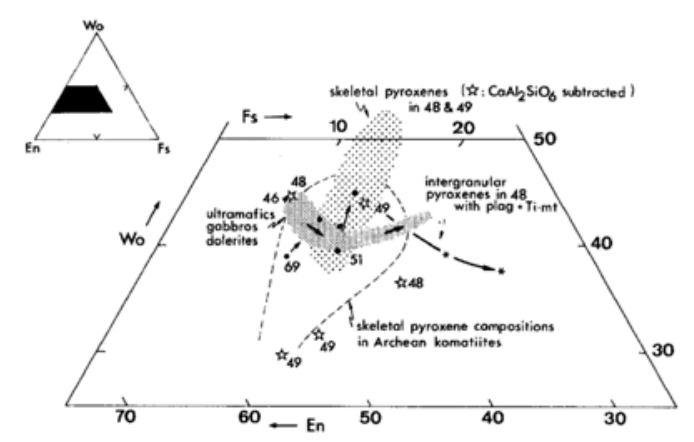

Fig. 6. Pyroxene compositions from the Gorgona rocks within portion of the system $\mathrm{MgSiO}_{3}-\mathrm{FeSiO}_{3}-\mathrm{CaSiO}_{3}$. All $\mathrm{Fe}$ is expressed as $\mathrm{Fe}^{2+}$. Close stippled field: compositional variation within ultramafic cumulates, gabbros, dolerites and basalts (e.g. No. 46, wehrlite). Nos. 69 and 51 represent extreme clinopyroxene compositions in picrite basalt and pillow basalt, respectively. Wide stippled field: skeletal pyroxenes in the komatiite flow 48 and 49 and path of iron enrichment of intergranular pyroxene. Stars: same pyroxenes, but Tschermaksmolecule $\mathrm{CaAl}_{2} \mathrm{SiO}_{2}$ subtracted. For comparison skeletal pyroxene composition (enclosed field) in Archean komatiites (CAMERON et al., 1979). 
stage quenched clinopyroxenes in the komatiites. The picrite basalt contains the most Mg-rich clinopyroxene microphenocrysts $\left(\mathrm{En}_{49.7}\right.$ and low $\mathrm{TiO}_{2}$ of $0.26 \mathrm{wt} . \%$ ). Thus these minerals along with olivine $\left(\mathrm{Fo}_{91}\right)$ represent near liquidus phases.

Spinels Spinel analyses are listed in Table 4. The magnesiochromites of the komatiitic flow occur as tiny skeletal (pseudo-euhedral) grains often assembled in patches within or close to the large quenched olivine plates. Although only two magnesiochromites with relatively high $\mathrm{MgO}$ (max. 16.7 wt.\%) and $\mathrm{Cr}_{2} \mathrm{O}_{3}$ (max. 46.4 wt.\%) but low $\mathrm{FeO}$ values are given, their compositional variations in the centre (No 48) and margin (No 49) of the komatiitic flow are shown in Fig. 7. Statistically, the rims of the magnesiochromites are higher in Cr. All Gorgona spinels have lower $\mathrm{Cr}$ and $\mathrm{Fe}^{2+}$ values than those in the Archean komatiites, but they are very similar to the spinels from aphyric olivine tholeiites of the Mid-Atlantic ridge.

In contrast to the quenched magnesiochromites titanomagnetite is disseminated as tiny euhedral grains in the arborescent groundmass of plagioclase and Fe-rich clinopyroxene (Fig. 4). Table 3 also shows selected spinel analysis of wehrlite (No 46), pillow-basalt (No 51) and picrite basalt (No 69). In coincidence with olivine $\mathrm{Fo}_{91}$ the spinels in the picrite basalt have $\mathrm{Cr}_{2} \mathrm{O}_{3}$ values of up to $47 \mathrm{wt} . \%$, whereas iron-rich magnesiochromites (Fig. 7) are present in the cumulate rocks (e.g. olivine gabbro No 59: $\mathrm{Cr}_{2} \mathrm{O}_{3}$ $=34$ to $42 \mathrm{wt} . \%$ and $\mathrm{FeO}_{\text {total }}=15$ to $33 \mathrm{wt} . \%$ ).

Plagioclase In the komatiites, plagioclase forms the interstitial arborescent material together with iron-rich clinopyroxene and titanomagnetite. The compositional range is from $\mathrm{An}_{\mathbf{8 1 - 7 5}}$ in the cores and decreasing to $\mathrm{An}_{60}$ in the rims of few zoned laths.

High - calcic plagioclase has been found only in the cumulate rocks (No 59: $A n_{88}$ ), picrite basalt $\left(\mathrm{An}_{80-78}\right)$, and in the wehrlite $\left(\mathrm{An}_{80-78}\right)$. In the pyroxene gabbros and dolerites, plagioclase proves to be more sodic (gabbro No 60: $\mathrm{An}_{65-60}$,

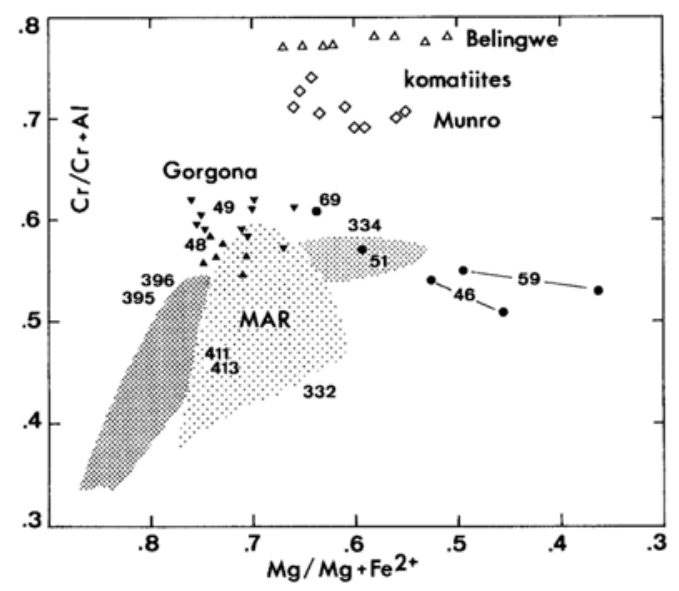

Fig. 7. Chrome spinel compositions expressed in terms of $\mathrm{Cr} /(\mathrm{Cr}+\mathrm{Al})$ and $\mathrm{Mg} /\left(\mathrm{Mg}+\mathrm{Fe}^{2+}\right)$ for the Gorgona rocks: filled triangles 48 and $49=$ komatiites; filled circles $=$ cumulates (No. 46 wehrlite, No. 59 olivine gabbro; open circles $=$ basalts (No. 69 picrite basalt, No. 51 pillow basalt). $\mathrm{Fe}^{2+}$ was calculated assuming stoichiometry. For comparison spinels from Archean komatiites (Munro, Canada and Belingwe, Rhodesia; data from CAMERON et al., 1979) and ocean floor basalts from Mid-Atlantic ridge (MAR DSDP sites 332, 334, 395, 396, 411, 413) and Nazca plate (DSDP Leg 34, site 319). References in Fig. 10 and SIGURDSSON and SCHILLING (1976), CLARKE and LOUBAT (1977), SIGURDSSON (1977).

gabbro No 45: $\mathrm{An}_{25-10}$ and dolerite No 47: $\mathrm{An}_{60-30}$ ).

\section{Bulk Chemistry}

Major elements (Tables 5 and 7) The basaltic rocks are hypersthene-normative and contain up to $20 \%$ olivine in the norm; and the picrite basalt even extend to $40 \%$ normative olivine. They overlap in composition with the basalts analysed by ECHEVERRIA (1980). The dolerites (e.g. No 47), which together with the basaltic rocks fill the field of mid-ocean ridge basalts are quartz-normative (THOMPSON et al., 1972) in the quartz-diopside-hypersthene-olivine-nepheline normative diagram

The komatiitic rocks plot outside this basaltic field, yielding higher normative olivine values of $27 \%$ (Table 7). Outstanding chemical features of these rocks are high $\mathrm{MgO}$ (12 and $16.6 \mathrm{wt} . \%$ resp.; atomic $\mathrm{Mg} / \mathrm{Mg}+\mathrm{Fe}^{2+}: 0.72$ and 0.74 ), low $\mathrm{TiO}_{2}(0.75$ and 0.69 wt.\% $), \mathrm{CaO} / \mathrm{Al}_{2} \mathrm{O}_{3}$ ratios 
Table 7. Chemistry of the Gorgona komatiites and of a fractional crystallisation model

\begin{tabular}{|c|c|c|c|c|c|c|c|}
\hline \multirow[b]{2}{*}{$\begin{array}{l}\text { Sample No. } \\
\text { Major oxides, } \\
\text { wt. \% }\end{array}$} & \multicolumn{7}{|c|}{ Komatiite flow (Punta Trinidad) } \\
\hline & $\begin{array}{c}48 \text { (cer } \\
\text { Av. of } 4 \\
\text { determinations }\end{array}$ & \multirow{2}{*}{$\begin{array}{c}\text { atre) } \\
\text { Calcd. } \\
\text { anhydrous }\end{array}$} & \multicolumn{2}{|c|}{$\begin{array}{l}\text { 48, Averages of } \\
\text { interstitial } \\
\text { quenched glass }\end{array}$} & \multirow{2}{*}{$\begin{array}{c}\begin{array}{c}\text { Av. of } 4 \\
\text { determinations }\end{array} \\
44.0\end{array}$} & \multirow{2}{*}{$\begin{array}{c}\begin{array}{c}\text { urface) } \\
\text { Calod. } \\
\text { anhydrous }\end{array} \\
45.8\end{array}$} & \multirow{2}{*}{$\begin{array}{c}\text { Basalt } 48 \\
\begin{array}{c}\text { Fractional crystallisa- } \\
\text { s tion model }-25 \% \text { ol }\end{array} \\
47.8\end{array}$} \\
\hline $\mathrm{SiO}_{2}$ & 44.2 & & 49.2 & 47.6 & & & \\
\hline $\mathrm{TiO}_{2}$ & 0.66 & 0.69 & 0.78 & 0.54 & 0.72 & 0.75 & 0.89 \\
\hline $\mathrm{Al}_{2} \mathrm{O}_{3}$ & 12.0 & 12.6 & 11.6 & 12.7 & 12.6 & 13.1 & 16.22 \\
\hline $\mathrm{Fe}_{2} \mathrm{O}_{3}$ & 3.2 & 1.3 & n.d. & n.d. & 4.0 & 1.3 & 4.32 \\
\hline $\mathrm{FeO}$ & 8.2 & 10.3 & $10.22^{*}$ & $10.60^{*}$ & 7.6 & 10.5 & 8.15 \\
\hline $\mathrm{MnO}$ & 0.18 & 0.19 & 0.22 & 0.30 & 0.18 & 0.19 & 0.24 \\
\hline $\mathrm{MgO}$ & 15.9 & 16.6 & 9.8 & 7.8 & 14.2 & 12.0 & 7.09 \\
\hline $\mathrm{CaO}$ & 10.1 & 10.5 & 16.7 & 16.4 & 11.5 & 12.0 & 13.64 \\
\hline $\mathrm{Na}_{2} \mathrm{O}$ & 1.13 & 1.18 & 1.22 & 1.10 & 1.05 & 1.09 & 1.53 \\
\hline $\mathrm{K}_{2} \mathrm{O}$ & 0.02 & 0.02 & $\langle .01$ & 0.01 & 0.07 & 0.07 & 0.27 \\
\hline $\mathrm{P}_{2} \mathrm{O}_{5}$ & 0.06 & 0.06 & n.d. & n.d. & 0.06 & 0.06 & 0.078 \\
\hline $\mathrm{Cr}_{2} \mathrm{O}_{3}$ & 0.19 & 0.20 & 0.11 & 0.14 & 0.17 & 0.18 & - \\
\hline $\mathrm{NiO}$ & 0.09 & 0.09 & n.d. & n.d. & 0.07 & 0.07 & - \\
\hline $\mathrm{H}_{2} \mathrm{O}^{+}$ & 4.0 & & & & 3.7 & & \\
\hline Total & 100.0 & 100.0 & 99.85 & 97.19 & 100.0 & 100.0 & 100.2 \\
\hline \multirow{2}{*}{$\begin{array}{l}\mathrm{Mg} /\left(\mathrm{Mg}+\mathrm{Fe}^{2+}\right) \\
\mathrm{X}_{\mathrm{Ol}}^{\mathrm{Mg}}\end{array}$} & \multirow{2}{*}{\multicolumn{2}{|c|}{0.74}} & \multirow{2}{*}{\multicolumn{2}{|c|}{$\begin{array}{l}\text { * Total iron } \\
\text { as } \mathrm{FeO}\end{array}$}} & \multirow{2}{*}{\multicolumn{2}{|c|}{0.72}} & 0.53 \\
\hline & & & & & & & 83.8 \\
\hline \multicolumn{8}{|c|}{ Normative Mineralogy (CIPW norm, wt.\%) } \\
\hline Or & \multicolumn{2}{|c|}{0.1} & 0.06 & 0.06 & \multicolumn{2}{|l|}{0.4} & 1.6 \\
\hline $\mathrm{Ab}$ & \multicolumn{2}{|c|}{10.0} & 10.4 & 9.6 & \multicolumn{2}{|l|}{9.2} & 12.9 \\
\hline An & \multicolumn{2}{|c|}{29.0} & 26.2 & 30.6 & \multicolumn{2}{|l|}{30.7} & 36.5 \\
\hline $\mathrm{Di}$ & \multicolumn{2}{|c|}{18.3} & 46.3 & 43.8 & \multicolumn{2}{|l|}{23.0} & 25.2 \\
\hline Hy & \multicolumn{2}{|c|}{11.2} & 5.9 & 7.8 & \multicolumn{2}{|l|}{6.4} & 10.4 \\
\hline Ol & \multicolumn{2}{|c|}{27.7} & 8.3 & 5.6 & \multicolumn{2}{|l|}{26.6} & 9.4 \\
\hline Mt & \multicolumn{2}{|c|}{1.9} & 1.4 & 1.4 & \multicolumn{2}{|l|}{1.9} & 1.6 \\
\hline $\mathrm{Cm}$ & \multicolumn{2}{|c|}{0.3} & - & - & \multicolumn{2}{|l|}{0.2} & - \\
\hline Il & & & 1.5 & 1.1 & 1.4 & & 1.7 \\
\hline Ap & & & - & - & 0.1 & & 0.2 \\
\hline
\end{tabular}

Norms and $\mathrm{Mg} /\left(\mathrm{Mg}_{\mathrm{Fe}}^{2+}\right)$ were calculated assuming $\left.\mathrm{Fe}^{3+}+\mathrm{Fe}^{3+}\right)=0.1$.

Basalt 48: calculated composition extracting $25 \%$ olivine in 5 steps of $\left(X_{01}^{M g}: 92,91,90,88,86.5\right)$

between 0.92 and 0.87 and relatively low alkaline concentrations (total average $\mathrm{Na}_{2} \mathrm{O}+$ $\mathrm{K}_{2} \mathrm{O} \sim 1.2$ wt.\%). These values fulfil the chemical characteristics of Archean komatiitic basalts defined during the Penrose Conference on komatiites (ARNDT and BRoOKs, 1980). Exceptional are the $\mathrm{MgO}$ contents which are below the lower limits of $18 \mathrm{wt} . \%$ in peridotitic komatiites, but similar to those of pyroxenitic composition (ARNDT et al., 1977; ARTH et al., 1977) and probably close to basaltic type komatiites (NESBITT et al., 1979) giving $\mathrm{CaO} / \mathrm{Al}_{2} \mathrm{O}_{3}$ ratios of $0.8-1.0$ and $\mathrm{Al}_{2} \mathrm{O}_{3} / \mathrm{TiO}_{2}$ ratios of $\sim 18$. Few higher $\mathrm{MgO}$ values have been reported by ECHEVERRIA (1980) from one komatiitic flow on Gorgona island. The basaltic and doleritic rocks have $\mathrm{MgO}$ between 8.9 and 6.6 wt.\% (Mg-No: 0.65 to 0.54 ), $\mathrm{TiO}_{2}$ between 0.9 and 1.3 wt.\% and $\mathrm{Na}_{2} \mathrm{O} \sim 3$ wt. $\%$.

The plutonic rocks indicate a rather wide compositional range, although, petrographically they consist mainly of olivine, clinopyroxene and plagioclase. The wehrlite (No 46) and the olivine gabbro (No 59) represent cumulate rocks (MgO: 30.2 and 20.6 wt.\%; $\mathrm{TiO}_{2}: 0.28$ and 0.33 wt.\%) whereas the gabbros (No 45 and 60) are more evolved plutonics (MgO: 6.1 and 7.4 wt.\%; $\mathrm{TiO}_{2}: 0.91$ and $1.1 \mathrm{wt} \%$ ). Alteration (serpentinisation of olivine) is shown by the high $\mathrm{H}_{2} \mathrm{O}$ contents and slightly high $\mathrm{Fe}_{2} \mathrm{O}_{3}$ values.

The bulk composition of the picrite basalt (No 69) is significantly low in $\mathrm{SiO}_{2}, \mathrm{TiO}_{2}$ and 
alkaline contents, but high in $\mathrm{MgO}$ (22.7wt.\%).

Trace elements (Table 5) The analysed komatiitic rocks yield high contents of $\mathrm{Ni}$ (560 and 720ppm) and $\mathrm{Cr}$ (1180 and 1250ppm).This is four times higher than $\mathrm{Ni}$ and $\mathrm{Cr}$ values in the pillow basalts. $\mathrm{Rb}, \mathrm{Sr}, \mathrm{Ba}$, and $\mathrm{Sc}$ abundances are in the same ranges as in the Archean pyroxenite komatiites from Munro Township (ARTH et al., 1977). Relative to basaltic and doleritic rocks Sc and V are slightly depleted. The same is evident for the incompatible elements, such as $\mathrm{Y}, \mathrm{Zr}, \mathrm{Nb}, \mathrm{Rb}$ and $\mathrm{Ga}$. $\mathrm{Zn}$ and $\mathrm{Cu}$ have intermediate concentrations relative to cumulate rocks and basalts.

Rare earth elements (Table 6) The chondritenormalized REE patterns of the different rock types (Fig. 8) show similar characteristics to each other. All the rocks have low total REE contents and show a depletion of the light rare earth elements (LREE): picrite basalt with $(\mathrm{Ce} / \mathrm{Sm})_{\mathrm{N}}$ ratio of 0.187 , cumulate rocks $0.27-$ 0.32 , the komatiites 0.34 , gabbros $0.40-0.67$, basalts 0.76 and dolerites 0.8 . The REE abundances from other komatiitic occurrences of Gorgona island (ECHEverria, 1980) are very similar, though LREE values are somewhat

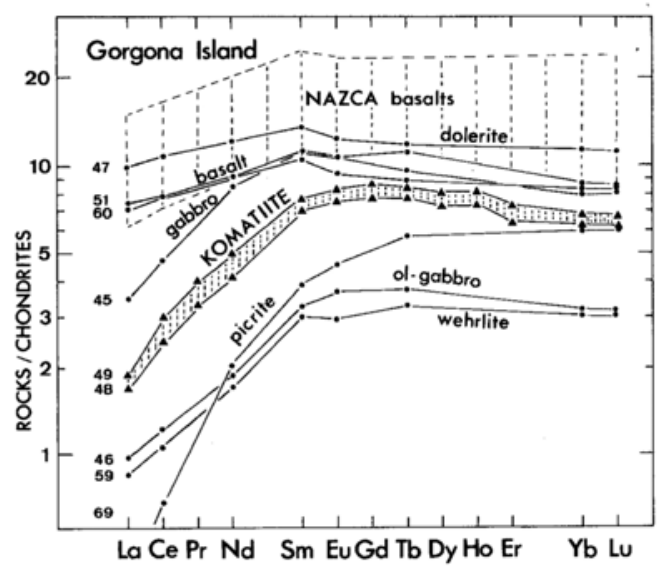

Fig. 8. Chondrite normalised (NAKAMURA, 1974) rare earth patterns of Gorgona komatiites, cumulate rocks, gabbros, dolerites and basalts. Hatched field: range of reported values for Nazca plate basalts (DSDP Leg 34, sites 319A, 320B, 321; THOMPSON et al., 1976). higher. The REE pattern of the Archean komatiites overlaps the field of those from Gorgona. In general LREE contents of the pyroxenitic komatiites of Munro Township (ARTH et al., 1977) are higher, thus the slopes are flattened. Relative to the komatiites, LREE of the Gorgona basalts and dolerites are slightly enriched. In contrast a weak negative slope of the heavy rare earth element (HREE) curves is evident in most of the rokcs. Again the picrite basalt is abnormal with strong LREE depletion and HREE enrichment. Weak Euanomalies are present in the dolerite and basalt.

\section{COMParison Between Gorgona Komatittes AND OCEAN FloOR Basalts}

The sequence of crystallisation in the komatiitic flow during rapid cooling can be divided in two stages:

- first stage of quenching: olivine $\left(\mathrm{Fo}_{91}\right)-$ magnesiochromite + high-Al clinopyroxene; - second stage of quenching: olivine $\left(\mathrm{Fo}_{83}\right)-$ Fe-rich clinopyroxene + plagioclase + titanomagnetite - glass

This sequence is compatible with the characteristic fractional crystallisation sequence observed in many ocean floor tholeiites. The remaining interplate glass in the spinifex komatiites with typical plumose extinction has a nearly basaltic composition (Table 7 and Fig. 9). Similar glass compositions have been reported from the other Gorgona komatiites by ECHEVERRIA (1980). The glass is enriched in $\mathrm{SiO}_{2}, \mathrm{TiO}_{2}$ and $\mathrm{CaO}$ but depleted in $\mathrm{MgO}$ and $\mathrm{Al}_{2} \mathrm{O}_{3}$. The latter contents result from the nonequilibrium crystallisation of olivine and the unusual high-Al clinopyroxenes (Table 3) during the first stage of quenching at temperatures between 1400 and $1500^{\circ} \mathrm{C}$. This explains the shift of the average glass composition towards the pyroxene corner in the PL-PX-OL normative diagram (Fig. 9).

In order to estimate an equilibrium crystallisation, which could produce a basaltic liquid from the pyroxenitic komatiitic composition at greater depth in a magma chamber, a fractional 


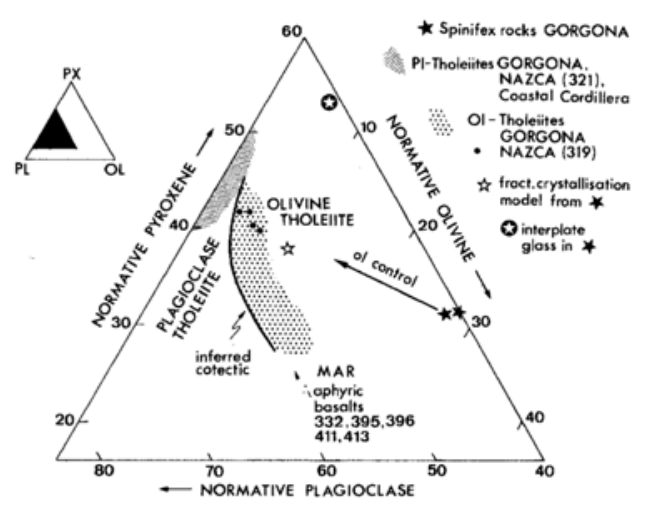

Fig. 9. Normative olivine-plagioclase-pyroxene relationships between the Gorgona spinifex rocks and aphyric Mid-Atlantic Ridge basalts (Leg 37, site 332, BLANCHARD et al., 1976; Legs 45 and 46, sites 395 and 396, DUNGAN et al., 1978 and RHODES et al., 1978; Leg 49, sites 411 and 413, WOOD et al., 1979) and Tertiary basalts from the Pacific (Nazca plate Leg 34, site 321, MAZZULLO and BENCE, 1976 and RHODES et al., 1976; Coastal Cordillera, GoossENS et al., 1977). The empirically determined olivine-plagioclase cotectic line is from SHIDO et al. (1971). The slope of the olivine control line has been calculated extracting $10 \%$ of forsterite from the Gorgona spinifex rocks.

crystallisation model has been calculated. A stepwise extraction of a total amount of $25 \%$ olivine (KD value of about 0.3 ) yields a mid-ocean ridge (MORB) olivine basalt (Table 7, Fig. 9). The latter composition is slightly different from the Gorgona basaltic rocks with higher values of $\mathrm{CaO}$ ( 13.6wt.\%) and $\mathrm{Al}_{2} \mathrm{O}_{3}$ (16.2 wt.\%) but lower values of $\mathrm{Na}_{2} \mathrm{O}$ and $\mathrm{K}_{2} \mathrm{O}$. An additional fractionation of $0.5 \%$ magnesiochromite as indicated by the $\mathrm{Cr}$ - and $\mathrm{Ni}$-distribution between the komatiites and basalts (Fig. 11) would increase $\mathrm{SiO}_{2}$ as well as decrease $\mathrm{Al}_{2} \mathrm{O}_{3}, \mathrm{MgO}$ and iron by a rather small portion. In order to reduce the $\mathrm{CaO}$ and $\mathrm{Al}_{2} \mathrm{O}_{3}$ contents, total amounts of ca. $5 \%$ of both clinopyroxene $\left(\sim \mathrm{En}_{45} \mathrm{Fs}_{9} \mathrm{Wo}_{46}\right)$ and anorthite might be incorporated in the fractional crystallisation model. The olivine fractionation is shown by the direction of the control line in the normative pyroxene-plagioclaseolivine diagram (Fig. 9). The arrow points to olivine tholeiites and subsequently to more evolved plagioclase tholeiites close to the inferred cotectic (SHIDO et al., 1971). Basalts from
Gorgona as well as from the Coastal Cordillera and Nazca plate (DSDP Leg 34, sites 319A, $320 \mathrm{~B}$ and 321) plot in the same area. For comparison aphyric olivine tholeiites from the Mid-Atlantic ridge (MAR) are also shown. Typical olivine tholeiites can therefore be derived from pyroxenitic komatiitic liquids by fractionation of 20 to $25 \%$ olivine and ca. $0.5 \%$ magnesiochromite; plagioclase tholeiites by additional fractionation of olivine, clinopyroxene and anorthite.

Figures 10 an 11 demonstrate the relationship between the Gorgona komatiites and aphyric ocean floor basalts based on Harkertype diagram: $\mathrm{Mg} / \mathrm{Mg}+\mathrm{Fe}^{2+}$ (with $\mathrm{Fe}_{2} \mathrm{O}_{3} / \mathrm{FeO}$ $=0.1$ ) versus critical major and trace elements. In the $\mathrm{SiO}_{2}$ and $\mathrm{CaO}$ plots the olivine control lines do not point exactly to the normal basaltic fields for the reason discussed above.

The low $\mathrm{CaO}$ and $\mathrm{Al}_{2} \mathrm{O}_{3}$ values of the evolved Gorgona dolerites (No 47) may be explained by an earlier accumulation of clinopyroxene and plagioclase. The picrite basalt (No 69) seems to represent an early cumulate carrying Fo-rich olivine, magnesiochromite and Mg-rich clinopyroxene.

In the trace element variation diagrams Fig. 11), the incompatible elements $\mathrm{Zr}$ and $\mathrm{Y}$ show linear correlations between the komatiites and basalts, indicating normal differentiation trends. With respect to primitive glasses and rocks from oceanic environments, $\mathrm{Cr}$ and $\mathrm{Ni}$ contents of the Gorgona komatiites are higher. Thus a fractionation of max. $0.5 \%$ magnesiochromite from the komatiitic liquid is necessary to produce the average $\mathrm{Cr}$ contents of 200-250 ppm in tholeiitic basalts. Normal MORB affinity (N-type after Wood et al., 1979) of the Gorgona komatiites is also indicated by the abundances (Table 6) and ratios of $\mathrm{Hf}, \mathrm{Th}$ and $\mathrm{Ta}$ : $\mathrm{Hf} / \mathrm{Th}$ ratio $=20, \mathrm{La} / \mathrm{Ta}=16.5$ and $\mathrm{Th} / \mathrm{Ta}=1.14$. The Ir content of $3.3 \mathrm{ppb}$ is surprisingly high and in the range of ultramafic mantle tectonites (JAGOUTZ et al., 1979 and P. HAMLYN, Lamont pers. comm.). Ocean floor tholeiites normally contain only up to $0.1 \mathrm{ppb}$ Ir (GoTTFRIED and GREenland, 1972; HeRTOGEN et al., 1980). This 

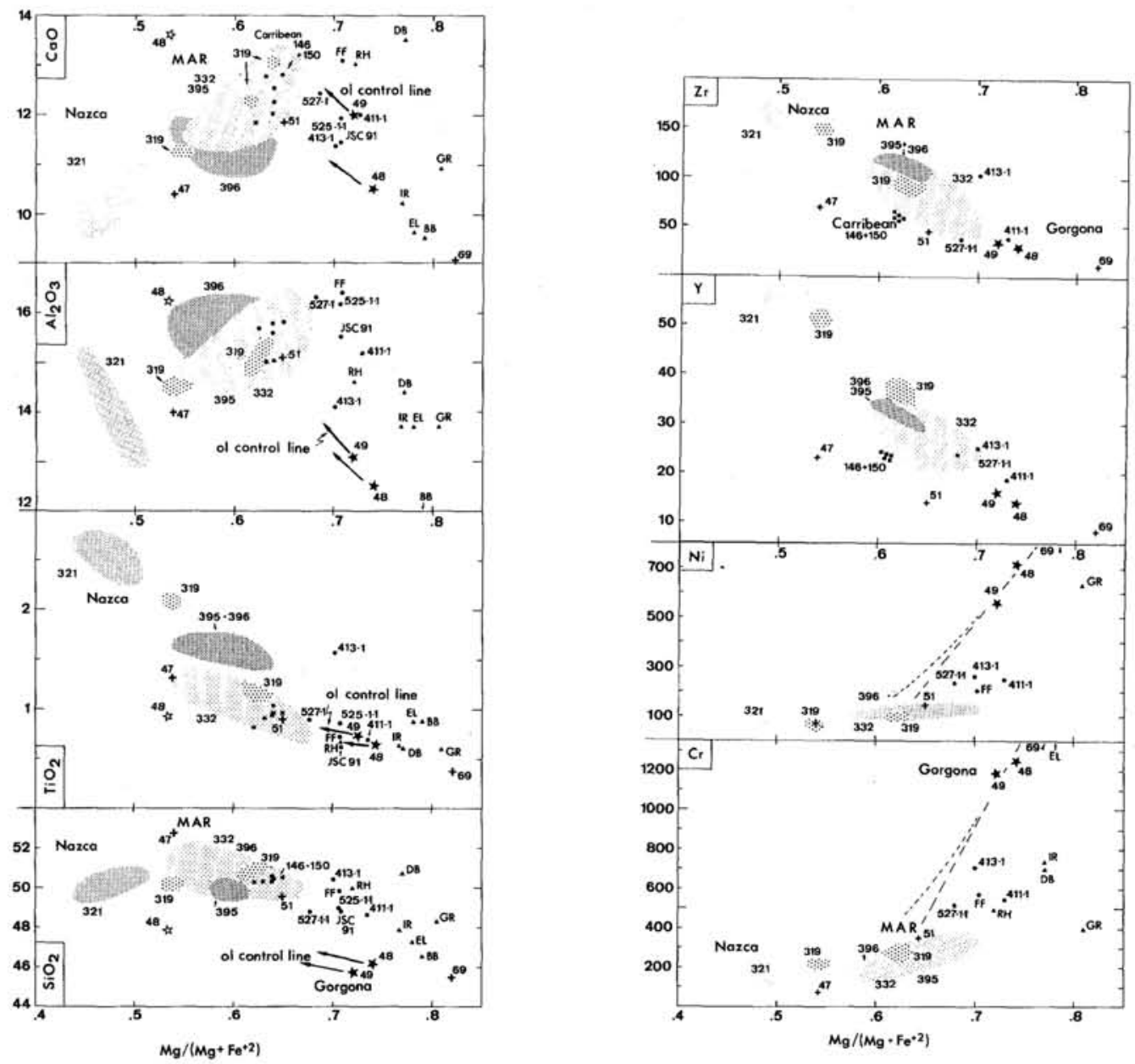

Fig. 10 and 11. Compositions of Gorgona komatiites (filled stars), fractional crystallisation model (open stars) and basalts (crosses) relative to fresh aphyric ocean floor from Mid-Atlantic ridge (MAR) and Nazca plate, few primitive basaltic glass and rock compositions and hypothetical primary magma compositions. Abscissa, atomic proportions assuming $\mathrm{Fe}_{2} \mathrm{O}_{3} / \mathrm{FeO}=0.1$.

References:

$B B=$ Baffin Bay tholeiite (O'NIONS and CLARKE, 1972)

$D B=$ Average comp. of melt inclusions in Cr-Al spinel, DSDP Leg 37, sites 332, 335 (DONALDSON and BROWN, 1974)

$\dot{E} L=$ High magnesia dyke NT23, Tortuga ophiolite complex, Chile (ELTHON, 1979)

$F F=D S D P$ 3-18 glass (FREY et al., 1974)

GR $=$ DSDP 3-18+17\% olivine (GREEN et al. 1978)

$I R=$ Calculated abyssal tholeiite (IR VINE, 1977)

$R H=$ Reconstructed composition of melt inclusion JSC 45G.1 in olivine, DSDP Leg 45 and 46, site $395 \mathrm{~A}$ (RHODES et al., 1978; DUNGAN and RHODES, 1978)

Nazca plate basalts: DSDP Leg 34, sites 319-321.

(KEMPE, 1976; MAZZULLO and BENCE, 1976; RHODES et al., 1976 and THOMPSON et al., 1976)

Mid-Atlantic ridge basalts:

JSC91: ol-basalt, DSDP Leg 37, site 332B (BLANCHARD et al., 1978)

411-1: DSDP Leg 49, site 411 (WOOD et al., 1979)

413-1: DSDP Leg 49, site 413 (WOOD et al., 1979)

525-5-1: Basalt glass, Famous area (BRYAN and MOORE, 1977)

Sites 332 (A+B): DSDP Leg 37 (FLOWER et al., $1977 a, b$ )

Sites 395 and 396: DSDP Leg 45 and 46 (DUNGAN et al., 1978; RHODES et al., 1978)

Basalts from the Central Caribbean:

Sites 146 and 150: DSDP Leg 15 (BENCE et al., 1975) 
suggests that Ir has remained in the residual ultramafics after separation of the basaltic melts. A problem seems to exist in fractionating olivine tholeiites from komatiitic primitive melts in respect to their depleted LREE abundances. A simple fractionation model of olivine and magnesiochromite, as it has been discussed on the basis of mineral chemistry, major and trace elements would only account for a slight increase of the LREE contents (REE contents in olivine taken from STOSCH and SECK, 1980) but not for the derivation of the normal LREE patterns in olivine tholeiites.

Magma mixing in chambers beneath midocean ridges has been discussed on the basis of different composition between entrapped melt inclusions in olivine and plagioclase and the bulk rock compositions as well as by disequilibrium textures in plagioclase phenocrysts from MAR basalts (DUNGAN and RHODES, 1978). A mixing process between a pre-existing, LREE enriched melt and the primitive komatiitic liquid could easily increase the mobile light rare earth element contents of the melt. Thus first stage fractionated olivine tholeiitic melts with slight depletion of LREE are getting progressively enriched in the light rare earth element abundances. The dolerites would require additional fractionation of clinopyroxene and plagioclase in order to yield the higher degree of LREE enrichment and the weak negative Eu-anomaly.

\section{Similarities between basaltic rocks from} Gorgona, the Coastal Cordillera and Nazca plate Clinopyroxene composition from Gorgona basalts resemble those of Nazca plate basalts (BUNCH and LA BORDE, 1976), but they are significantly different from clinopyroxene from island arc basalts and from tholeiitic basalts in oceanic islands (Nisbet and Pearce, 1977). Phenocrysts and greater model amounts of augite are typical for evolved Pacific basalts whereas MAR basalts are characterised by phenocrysts of plagioclase and olivine (CAMERON et al., 1980).

The normative scheme (Fig. 9) as well as the variation diagrams (Figs. 10 and 11) reveal general chemical similarities of the basaltic rocks from the different tectonic environments. A closer look shows that a more detailed comparison between the Gorgona rocks and basalts from the ophiolite suites in the Coastal Cordillera is rather difficult because of lack of data. GoosEns et al. (1977) have described low potassic ocean floor tholeiites similar to those from Gorgona and highly evolved tholeiites as well as basaltic andesites from island arc environments.

Palaeogene basalts from Nazca plate have been drilled in DSDP Leg 34, sites 319A, 320B and 321. While the Oligocene olivine basalts of site $319 \mathrm{~A}$ are rather primitive $\left(\mathrm{Mg} / \mathrm{Mg}+\mathrm{Fe}^{2+}\right.$ : $0.63-0.53 ; \mathrm{TiO}_{2}: 1.1-2.1$ wt.\%, Fig. 10) the Eocene basalts from site 321 are more evolved plagioclase-pyroxene tholeiites $\left(\mathrm{Mg} / \mathrm{Mg}+\mathrm{Fe}^{2+}\right.$ : 0.52-0.43; $\mathrm{TiO}_{2}: 2.3-2.7$ wt.\%). Petrogenetic relationships between ocean floor basalts from different tectonic environments can be deducted by the ratios of $\mathrm{Ce} / \mathrm{Zr}, \mathrm{Nb} / \mathrm{Zr}$ and $\mathrm{Ba} / \mathrm{Zr}$ (TARNEY et al., 1980). In this respect the Gorgona komatiites, basalts, dolerites and gabbros are very similar to the Nazca tholeiites of Leg 34, site 319 but different from the Mid-Atlantic ridge basalts. This applies also to the REE abundances (Fig. 8).

To explain the different types of basalts in the Nazca plate, particularly those of site 321 with high $\mathrm{TiO}_{2}$, high LIL element and REE abundances, more complex processes have been discussed. A mixing process of depleted asthenosphere with a juvenile mantle plume accompanied by shallow-depth olivine gabbro fractionation has been proposed by ScHILLING et al. (1976).

Komatiites as products of primary melt The discussion of the mantle source origin of the komatiitic liquids can be based on large-ionlithophile elements such as $\mathrm{K}, \mathrm{Rb}, \mathrm{Cs}, \mathrm{Sr}, \mathrm{Ba}$ (White and Schilling, 1978), on REE abundances and on $\mathrm{Sr}, \mathrm{Nd}$, and $\mathrm{Pb}$ isotope data. Oceanic mantle origin is indicated by low $\mathrm{K}, \mathrm{Rb}$, $\mathrm{Sr}, \mathrm{Ba}$ and total REE contents (5-8 times chondrites) as well as by LREE depletion shown by the ratio $(\mathrm{Sm} / \mathrm{Nd})_{\mathrm{N}}>=1.7-1.9$. The $\mathrm{Yb}$ 
content of the komatiites ( $\sim 15 \mathrm{ppm})$ in the sense of an indication for equiblibrium partial melting of a source peridotite (O'NIONS et al., 1978) requires approximately $18 \%$ partial melting of a lherzolite to produce the komatiitic liquid. This is the same value necessary to derive primitive tholeiites from Baffin Bay (composition shown as BB in Figs. 10 and 11). GreEN et al. (1978) inferred from olivine - addition studies to a primitive MAR glass (DSDP3-19, composition FF in Figs. 10 and 11) that a picritic magma (GR) close to the komatiitic composition has olivine and orthopyroxene as liquidus phases at $\sim 20 \mathrm{kbar}$ and $1430^{\circ} \mathrm{C}$, thus seggregated from residual harzburgite.

Further evidence for an oceanic mantle origin for the komatiites has been supported by ${ }^{87} \mathrm{Sr} /{ }^{86} \mathrm{Sr} \quad(0.7028-0.7035)$ and ${ }^{143} \mathrm{Nd} /{ }^{144} \mathrm{Nd}$ (0.5129-0.5133) ratios (ECHEVERrIA, 1980). The two ratios give a negative oceanic correlation trend (O'NIONS et al., 1977). The variation of the ratios has been interpreted as due to heterogeneous source regions in the mantle.

So far the available mineralogical and chemical evidence points to an explanation for the Gorgona komatiitic flows as being quenched products of a very primitive or primary melt. In addition the komatiites plot well between the distribution fields of aphyric ocean floor tholeiites, primitive glasses, entrapped melt inclusions and calculated primary magmas (Figs. 10 and 11). The basalts, dolerites and gabbros as well as the residual cumulate rocks of Gorgona island can therefore be derived from the initial komatiitic melt by fractionation and mixing processes.

Arguments against simple fractionation processes, deriving the Archean tholeiitic basalts from primary komatiitic melts have been brought up on the basis of trace element contents and of the mismatch of the LREE pattern. ARTH et al. (1977) and NESBITT et al. (1979) propose multistage melting models of peridotitic mantle at different depth producing primitive tholeiites apart from peridotitic komatiites, the latter fractionating to pyroxenitic and basaltic komatiites.

Gorgona island, an uplifted block of immature magma chambers The reason for the existence of the komatiitic flows on Gorgona island is difficult to explain. Similar occurrences have never been reported from any Phanerozoic ophiolite terrain or ocean floor. A structural and compositional setting comparable to that of Gorgona island have not been found: Small komatiitic lava flows interlayered within a basaltic and doleritic complex along the margins of the island. In addition picritic rocks exist on Gorgona island and the numerous ultramafic and mafic cumulates outcrop in the central parts. Intercalated oceanic sediments are missing except for Upper Eocene arenaceous limestones from the south ${ }_{1}$ ern tip of Gorgonilla island. Mineralogically and chemically all Gorgona plutonics and basaltic volcanics are similar to Oligocene basalts from Nazca plate oceanic crust.

Unfortunately, the structure and age of the Pacific oceanic crust off Colombia is rather poorly known (see Fig. 1). Bathymetric contours show a rather wide shelf and the shallow Colombia trench. This indicates that the topographic relief has been reduced over a long time span. Further west between Coiba, Malpelo and the more southern Carnegie ridge magnetic anomalies mark a spreading history of 25 to 8 million years (LONSDALE and KLITGaRD, 1978). The age of the Nazca plate crust between Yaguina graben and Colombia trench therefore could be Eocene or Oligocene. This is consistent with the oldest sediments that outcrop on Gorgona island, today incorporated in the Colombian shelf. The Colombia trench at least marks the trace of an earlier destructive continental margin, along which the Nazca plate has been subducted since Early Tertiary or even Upper Cretaceous.

An island arc environment for the Gorgona island could therefore be envisaged, however, neither structural nor geochemical evidence has been found to substantiate this hypothesis. The entire islands are made up of oceanic tholeiites. Boninites, island arc tholeiites or relicts of calc-alkaline rocks such as andesites and dacites, common in the Pacific island arcs, have not been found. 


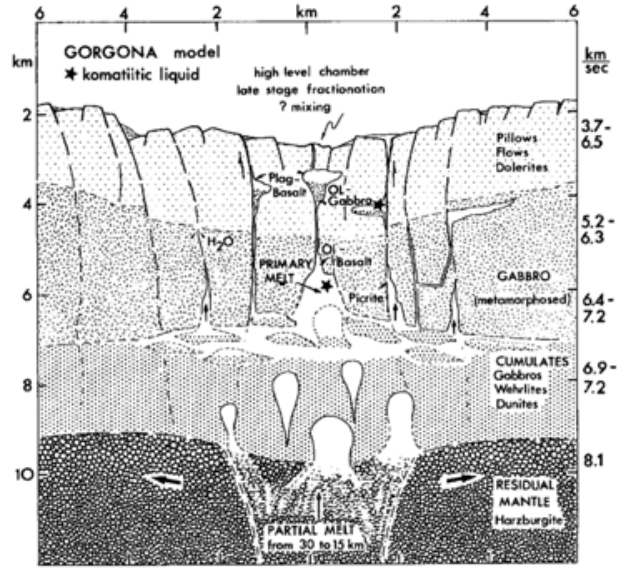

Fig. 12. Diagrammatic model of a central part of midocean ridge crust in order to explain the formation of small komatiitic lava flows on Gorgona island. Intense vertical and horizontal movements may have occurred during Eocene time. This process could have released enclosed melt from middle and high stage magma chambers and generated rapid ascend.

A simple model (Fig. 12) is proposed in order to explain the unusual structural setting of mafic and ultramafic rocks intercalated with minor komatiitic flows: Gorgona island itself may represent an uplifted block of immature magma chambers within the oceanic crust of the Nazca plate. The process of the initial uplift probably during Eocene from at least $2-4 \mathrm{~km}$ depths to the ocean floor is not yet understood. But it would account for a rapid ascent along faults and cooling of undifferentiated komatiitic liquids at high temperatures between 1300 and $1500^{\circ} \mathrm{C}$, for the formation of picrite basalts and for the existence of cumulate ultramafics in the central part of the island: Melting experiments on the Gorgona komatiites under pressures of 4,6 and $8 \mathrm{kbar}$ indicate crystallisation temperatures of 1300 to $1400^{\circ} \mathrm{C}$ (DIETRICH et al. in prep.). Intensive block faulting, as indicated by earlier surveilance (GANSSER, 1950; ECHEVERRIA and PARIS, 1978 in EcheVERrIA, 1980) would confirm this model. Gorgona island is compatible in terms of width and length with the small dimensions of the central part of the East Pacific Rise (Herron et al., 1980) as well as with the "infinite leek" model of the Mid-Atlantic Ridge in the FAMOUS area (NISBET and Fowler, 1978). The latter model would also explain more easily the mineralogical and chemical variations of the tholeiitic basalts and dolerites found on Gorgona island. They may be interpreted as results of different degrees of fractionation within small sized and periodically refilled magma chambers (O'HARA, 1977) at high levels.

Acknowledgements-The XRF analyses have been made with the assistance of A. ESENWEIN from theEidgenösische Materialprüfungsanstalt (EMPA), Dübendorf. B.W. CHAPPEL (Australian National University, Canberra) and H. PALME (Max-Planck-Institut, Mainz) provided additional trace element data for the komatiites. Neutron activation analyses of the rare earth elements were carried out by S. BAJO and A. WYTTENBACH at the Eidgenössisches Institut für Reaktorforschung (EIR), Würenlingen. S. R. TAYLOR (Australian National University, Canberra) kindly supplied spark source mass spectrometry analyses for the komatiites.

We thank E. G. NISBET (Cambridge) for helpful criticism and B. GUNTER and P. KOONS (Zürich) for a thorough review which greatly improved the manuscript.

\section{REFERENCES}

AKASAKA, M. and ONUMA, K. (1980) The join $\mathrm{CaMgSiO}_{6}-\mathrm{CaFeAlSiO}_{6}-\mathrm{CaTiAl}_{2} \mathrm{O}_{6}$ and its bearing on the Ti-rich pyroxenes. Contrib. Mineral. Petrol. 34, 272-287.

ARndT, N. T. and Brooks, C. (1980) Penrose Conference report: Komatiites. Geology 8, 155-156.

ARndT, N. T., NALDRETT, A. J. and PYKe, D. R.(1977) Komatiitic and iron-rich tholeiitic lavas of Munro Township. Northeast Ontario. J. Petrol. 18, 319 -369 .

ARTH, J. G., ARNDT, N. T. and NALDRETT, A. J. (1977) Genesis of Archean komatiites from Munro Township, Ontario: trace element evidence. Geology 5, 590 -594 .

Auboin, J. (1973) A presentation of the Andean Belt. Rev. Geogr. Phys. Geol. Dynam., Numéro spécial sur les Andes, 15, 5-10.

BAJO, S and WYTTENBACH, A. (1980) Extraction liquide-liquide des terres rares et application à leur dosage dans les silicates par activation neutronique. EIR Techn. Mitt. (internal report) TM-44-80-2, 20p.

BANDY, O. L. (1970) Upper Cretaceous-Cenozoic paleobathymeteric cycles, eastern Panama and northern Colombia. Gulf Coast Assoc. Geol. Socs. 
Trans. 20, 181-193.

BenCE, A. E., PAPIKE, J. J. and Ayuso, R. A. (1975) Petrology of submarine basalts from the central Caribbean. DSDP Leg 15. J. Geophys. Res. 80, 4775-4804.

BENDER, J. F., HodGeS, F. N. and BENCE, A. E. (1978) Petrogenesis of basalts from project Famous area: experimental study from 0 to $15 \mathrm{kbars}$. Earth planet. Sci. Lett. 41, 277-302.

Blanchard, D. P., Rhodes, J. M., DUnGan, M. A., RODGERS, K. V., DONALDSON, C. H., BRANNON, J. C., JACOBS, J. W. and GIBSON, E. K. (1976) The chemistry and petrology of basalts from Leg 37 of the Deep Sea Drilling Project. J. Geophys. Res. 81, 4231-4246.

BOETTCHER, A. L., MYSEN, B. O. and MODRESKI, P. J. (1975) Phase relationships in natural and synthetic peridotite $-\mathrm{H}_{2} \mathrm{O}$ and peridotite- $\mathrm{H}_{2} \mathrm{O}-\mathrm{CO}_{2}$ systems at high pressures. Phys. Chem. Earth Inter. 9, 855-867.

BRYAN, W. B. and MOORE, J. G. (1977) Compositional variations of young basalts in the Mid-Atlantic ridge rift valley near lat $36^{\circ} 49^{\prime}$ N. Geol. Soc. Am. Bull. 88, 556-570.

BUNCH, T. E. and LABORDE, R. (1976) Mineralogy and compositions of selected basalts from DSDP Leg 34, In: Init. Rep. Deep Sea Drilling Proj. 34, 263-275.

BUTTERLIN, J. (1973) Comparison des caracteres structuraux des Cordilleras sud-americaines extraandines, des Andes Centrales et des Andes Septentrionales. II Cong. Lat. Amer. Geol. Caracas, 31p.

CAmeron, W. E., Nisbet, E. G. and Dietrich, V. J. (1979) Boninites, komatiites and ophiolitic basalts. Nature 280, 550-553.

CAMERon, W. E., Nisbet, E. G. and Dietrich, V. J. (1980) Petrographic dissimilarities between ophiolitic and ocean floor basalts. Proc. Internat. Ophiolite Symposium, Cyprus 1979, 182-192.

ClaRKE, D. B. and LOUBAT, H.(1977) Mineral analyses from the peridotite-gabbro-basalt complex at Site 334, DSDP Leg 37. In: Init. Rep. Deep Sea Drilling Proj. Leg 37, 847-855.

DiETrich, V., EMmermanN, R., OBERHAENSLI, R. and PUCHELT, H. (1978) Geochemistry of basaltic and gabbroic rocks from the West Mariana basin and the Mariana trench. Earth planet. Sci. Lett. 39, 127-144.

Dietrich, V. J., KoONS, P. and Sommerauer, J. (in preparation) Melting experiments on the Gorgona komatiites.

Dietrich, V., Oberhaenslt, R. und WaLPEN, P. (1976) Röntgenfluoreszenzanalyse der Silikatgesteine (internal report). Institut für Kristallographie und Petrographie der ETH-Zürich.

DONALDSON, C. H. and BROWN, R. W. (1977) Refrac- tory megacrysts and magnesium-rich melt inclusions within spinel in oceanic tholeiites: Indicators of magma mixing and parental magma composition. Earth planet. Sci. Lett. 37, 81-89.

DUQUE, C. H. (1972) Relaciones entre la bioestratigrafia y la cronoestratigrafia en el ilamado geosynclinal de Bolivar. Colombia Bol. Geológico 19, 3, 25-68.

DungaN, M. A. and RHodes, J. M. (1978) Residual glasses and melt inclusions in basalts from DSDP Legs 45 and 46: evidence for magma mixing. Contrib. Mineral. Petrol. 67, 417-431.

Dungan, M. A., RHODES, J. M., LONG, P. E., BLANCHARD, D. P., BRANNON, J. C. and RODGERS, K. V. (1978) The petrology and geochemistry of basalts from site 396-legs 45 and 46 of the Deep Sea Drilling Project. In: Init. Rep. Deep Sea Drilling Proj. 46, 89-113.

ECHEVERRIA, L. M. (1980) Tertiary or Mesozoic komatiites from Gorgona Island, Colombia: Field relations and geochemistry. Contrib. Mineral. Petrol. 73, 253-266.

ELtHON, D. (1979) High magnesia liquids as the parental magma for ocean floor basalts. Nature 278, 514-518.

ENGI, M. (1978) Mg-Fe equilibria among Al-Cr spinel, olivine, orthopyroxene and cordierite. $\mathrm{Ph}$. D. thesis, ETH Zürich.

FAUCHER, B. and SAVoyat, E. (1973) A geological draft for the Equator Andes. Rev. Geogr. Phys. Geol. Dynam., Numéro spécial sur les Andes, 15, 115-142.

FLOWER, M. F. J., ROBINSON, P. T. and SCHMINCKE, H.U.(1977a) Petrology and geochemistry of igneous rocks, DSDP Leg 37. In: Init. Rep. Deep Sea Drilling Proj. 37, 653-680.

FLOWER, M. F. J., ROBINSON, P. T., SCHMINCKE, H. U. and OHNMACHT, W. (1977b) Magma fractionation systems beneath the Mid-Atlantic ridge at $36-37^{\circ} \mathrm{N}$. Contrib, Mineral. Petrol. 64, 167-195.

FREY, F. A., BRYAN, W. B. and THOMPSON, G. (1974) Atlantic Ocean floor: Geochemistry and petrology of basalts from legs 2 and 3 of the Deep-Sea Drilling Project. J. Geophys. Res. 79, 5507-5527.

GANSSER, A. (1950) Geological and petrological notes on Gorgona Island in relation to North-Western S. America. Schweiz. Mineral. Petrogr. Mitt. 30, 219-237.

GANSSER, A. (1973) Facts and theories on the Andes. J. Geol. Soc. Lond. 129, 93-131.

Gansser, A., Dietrich, V. J. and Cameron, W. E. (1979) Paleogene komatiites from Gorgona Island. Nature 278, 545-546.

GoOSENS, P. J., RoSE, W. I. JR., Flores, D. (1977) Geochemistry of tholeiites of the basic igneous com- 
plex of northwestern South America. Geol. Soc. Am. Bull. 88, 1711-1720.

GotTFRIED, D. and GREenLAND, L. P. (1972) Variation of iridium and gold in oceanic and continental basalts. Int. Geol. Congr. 24th 10, 135-144.

GREeN, D. H., HibBeRson, W. O. and JACQUes, A. L. (1978) Petrogenesis of mid-ocean ridge basalts. In The Earth: Its origin, structure and evolution, (M. W. McElhinny, editor). Academic Press London.

HERron, T. J., STOFFA, P. L. and BUHL, P. (1980) Magma chamber and mantle reflections - East Pacific Rise. Geophys. Res. Lett. 7, 11, 989-992.

HERTOGEN, J., JANSSENS, M.-J. and PALME, H. (1980) Trace elements in ocean ridge basalt glasses: implications for fractionations during mantle evolution and petrogenesis. Geochim. et Cosmochim. Acta. 44, 2125-2143.

HUEBNER, ST. (1980) Phase equilibria at low pressure. In Pyroxenes (C. T. PREWITT, ed.). Rev. in Mineral. 7, 213-288.

IRVINE, T. N. (1977) Definition of primitive liquid compositions for basic magmas. Yb. Carnegie Inst. Wash. 76, 454-461.

Jagoutz, E., Palme, H., Baddenhausen, H., Blum, K., Cendales, M., Dreibus, G., Spettel, B., LORENZ, V., and WAENKE, H. (1979) The abundances of major, minor and trace elements in the earth's mantle as derived from primitive ultramafic nodules. Proc. Lunar. Planet. Sci. Conf. 10th, 20312050.

KEMPE, D. R. C. (1976) Petrological studies on DSDP leg 34 basalts: Nazca plate, Eastern Pacific. In: Init. Rep. Deep Sea Drilling Proj. 34, 189-213.

LONSDALE, P. and KLITGORD, K. D. (1978) Structure and tectonic history of the eastern Panama Basin. Geol. Soc. Am. Bull. 89, 981-999.

MAZzUllo, L. J. and BENCE, A. E. (1976) Abyssal tholeiites from DSDP Leg 34: The Nazca plate. $J$. Geophys. Res. 81, 4327-4351.

MYSEN, B. O. and KUSHIRO, I. (1977) Compositional variations of coexisting phases with degree of melting peridotite in the upper mantle. Am. Miner. 62, 843-856.

NAKAMURA, N. (1974) Determiantion of REE, Ba, Fe, $\mathrm{Mg}, \mathrm{Na}$ and $\mathrm{K}$ in carbonaceous and ordinary chondrites. Geochim. Cosmochim. Acta 38, 757-775.

NeSBITT, R. W., SUN, S. -S. and PURVIS, A. C. (1979) Komatiites: geochemistry and genesis. Canad. Mineral. 17, 165-186.

Nisbet, E. G. and Fowler, C. M. R. (1978) The MidAtlantic Ridge at $37^{\circ}$ and $45^{\circ} \mathrm{N}$ : some geophysical and petrological constraints. Geophys. J. R. astr. Soc. 54, 631-660.

Nisbet, E. G. and PearCE, J. A. (1977) Clinopyroxene composition in mafic lavas from different tectonic settings. Contrib. Mineral. Petrol. 63, 149-160.

Nisbet, E. G., DieTrich, V. J. and ESENWEIN, A. (1979) Routine trace element determination in silicate minerals and rocks by X-ray fluorescence. Fortschr. Miner. 57, 264-279.

OBERHAENSLI, R., DIETRICH, V. J. and OBERHAENSLI, H. (1977) Maringeologische Untersuchungen im Westpazifik. Eclogae geol. Helv. 70, 417-434.

O'HARA, M. J. (1977) Geochemical evolution during fractional crystallization of a periodically refilled magma chamber. Nature 266, 503-507.

O'Nions, R. K. and ClarKe, D. B. (1972) Comparative trace element geochemistry of Tertiary basalts from Baffin Bay. Earth planet. Sci. Lett. 15, 436-446.

O'Nions, R. K., Evensen, N. M., Hamilton, P. J. and CARTER, S. R. (1978) Melting of the mantle past and present: isotope and trace element evidence. Phil. Trans. R. Soc. Lond. A. 288, 547-559.

O'NiONS, R. K., HAMILTON, P. J. and EVENSEN, N. M. (1977) Variations in ${ }^{145} \mathrm{Nd} /{ }^{144} \mathrm{Nd}$ and ${ }^{87} \mathrm{Sr} /{ }^{86} \mathrm{Sr}$ ratios in oceanic basalts. Earth planet. Sci. Lett. 34, 13-22.

PeIVE, A. V. (1980) Geology of the Philippine Sea Floor. Publishing Office Nanka, Moscow, 261 p. (in Russian).

PRESNALl, D. C., DiXon, J. R., O'DONELl, T. H. and DIXON, S. A. (1979) Generation of mid-ocean ridge tholeiites. J. Petrol. 20,3-35.

PYKe, D. R., NALDRETT, A. J. and ECKSTRAND, A. R. (1973) Archean ultramafic flows in Munro Township, Ontario. Geol. Soc. Am. Bull. 84, 955-978.

RHODES, J. M., BLANCHARD, D. P., DUNGAN, M. A., RODGERS, K. V. and BRANNON, J. C. (1978) Chemistry of leg 45 basalts. In: Init. Rep. Deep Sea Drilling Proj. 45, 447-459.

RHODES, J. M., BLANCHARD, D. P., RODGERS, K. V., JACOBS, J. W. and BRANNON, J. C. (1976) Petrology and chemistry of basalts from the Nazca plate: Part 2 - major and trace element chemistry. In: Init. Rep. Deep Sea Drilling Proj. 34, 239-244.

RoEder, P. L., CAMPELl, I. H. and JAMIESON, H. E. (1979) A re-evaluation of the olivine-spinel geothermometer. Contrib. Mineral. Petrol. 68, 325-334.

SCHILliNG, J. -G., ANDERSON, R. N. and VOGT, P. (1976) Rare earth, $\mathrm{Fe}$ and $\mathrm{Ti}$ variations along the Galapagos spreading centre, and their relationship to the Galapagos mantle plume. Nature 261, 108-113.

Shido, F. A., MiYashiro, A. and EWING, M. (1971) Crystallization of abyssal tholeiites. Contrib. Mineral. Petrol. 31, 251-266.

SIGURDSSON, H. (1977) Spinels in Leg 37 basalts and peridotites: phase chemistry and zoning. In: Init Rep. 
Deep Sea Drilling Proj. 37, 883-891.

SigurdSSON, H. and SCHILling, J. G. (1976) Spinels in Mid-Atlantic ridge basalts: chemistry and occurrence. Earth planet. Sci. Lett. 29, 7-20.

STOSCH, H. -G. and SECK, H. A. (1980) Geochemistry and mineralogy of two spinel peridotite suites from Dreiser Weiher, West Germany. Geochim. Cosmochim. Acta 44, 457-470.

TARNEY, J., SaUnders, A. D., Weaver, S. D., DONNEllan, N. C. B. and HENDRY, G. L. (1980) DSDP 9. Minor-element geochemistry of basalts from Leg 49, North Atlantic Ocean. In: Init. Rep. Deep Sea Drilling Proj. 49, 657-692.

TAYLOR, S. R. and GORTON, M. P. (1977) Geochemical application of spark source mass spectrometry III. Geochim. Cosmochim. Acta 41, 1375-1380.

THOMPSON, G., BRYAN, W. B., FREY, F. A. and SUEN,
C. J. (1976) Petrology and geochemistry of basalts from DSDP Leg 34, Nazca plate. In: Int. Rep. Deep Sea Drilling Proj. 34, 189-213.

ThOMPSON, G., SHido, F. and MiYAShiro, A. (1972) Trace element distributions in fractionated oceanic basalts. Chem. Geol. 9, 89-97.

White, W. M. and Schilling, J. -G. (1978) The nature and origin of geochemical variation in MidAtlantic Ridge basalts from the Central North Atlantic. Geochim. Cosmochim. Acta 42, 1501-1516.

WOOD, D. A., TARneY, J., VARET, J., SAUnders, A. D., Bougault, H., Joron, J. L., Treul, M., CANN, J. R. (1979) Geochemistry of basalts drilled in the North Atlantic by IPOD Leg 49: implications for mantle heterogeneity. Earth planet. Sci. Lett. $\mathbf{4 2}$, 77-97. 


\section{FIGURE FOR REPLACEMENT}

For the paper "Palaeogene komatiites from Gorgona Island, East Pacific - A primary magma for ocean floor basalts?" by V. J. Dietrich et al., please replace Fig. 12 on page 158 of this volume with this figure.

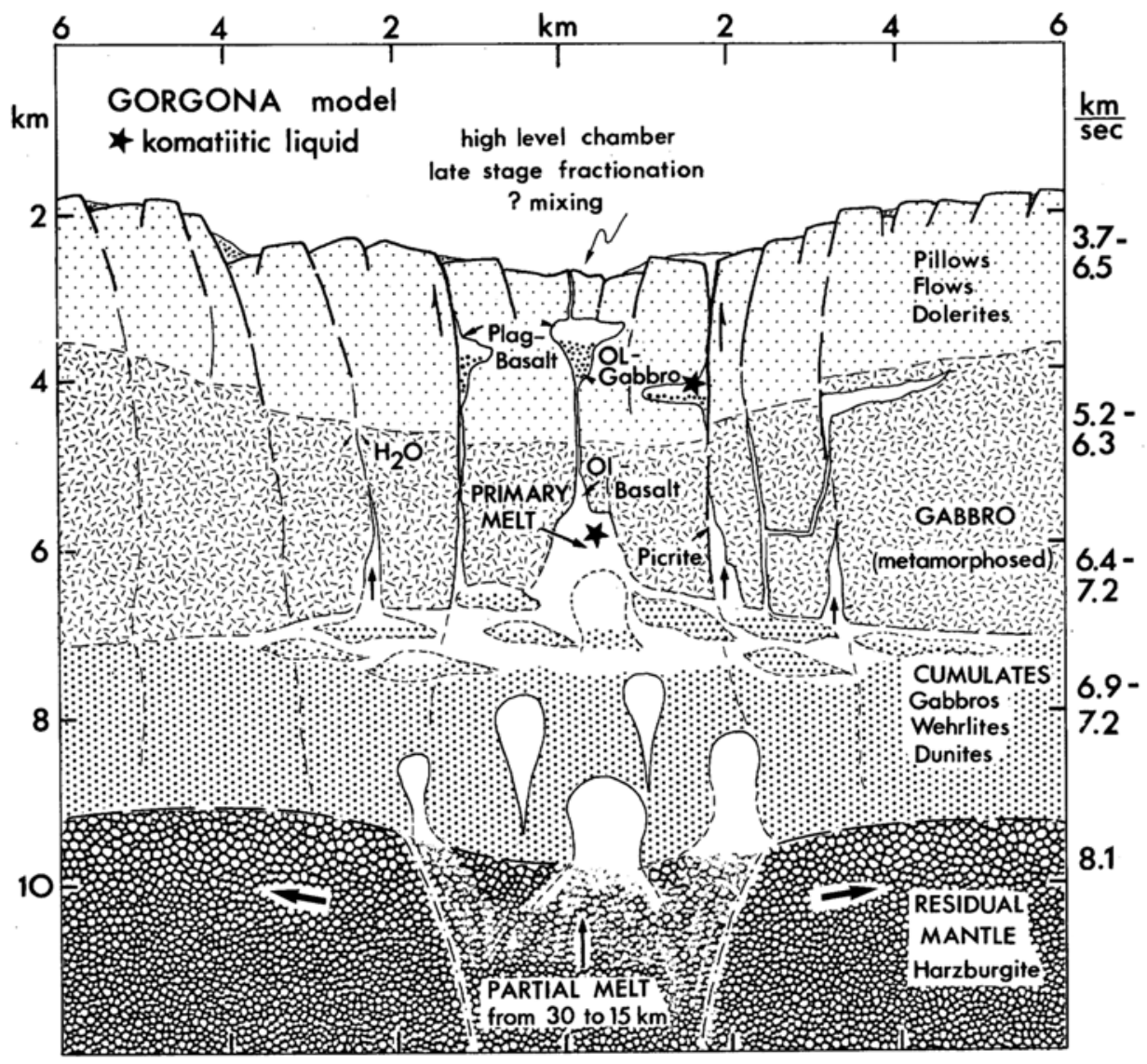

Fig. 12 Diagrammatic model of a central part of midocean ridge crust in order to explain the formation of small komatiitic lava flows on Gorgona island. Intense vertical and horizontal movements may have occurred during Eocene time. This process could have released enclosed melt from middle and high stage magma chambers and generated rapid ascend. 